\title{
INTERLEUKIN-13 AS AN IMPORTANT CYTOKINE: A REVIEW ON ITS ROLES IN SOME HUMAN DISEASES
}

\author{
NARGES SEYFIZADEH ${ }^{1,2}$, NAYER SEYFIZADEH ${ }^{3,4}$, TOHID GHARIBI ${ }^{2}$ \\ and ZOHREH BABALOO ${ }^{1 *}$ \\ ${ }^{1}$ Immunology Research Center, Tabriz University of Medical Sciences, Tabriz, Iran \\ ${ }^{2}$ Immunology Department, Faculty of Medicine, Tabriz University of Medical Sciences, \\ Tabriz, Iran \\ ${ }^{3}$ Umbilical Cord Stem Cell Research Center, Tabriz University of Medical Sciences, \\ Tabriz, Iran \\ ${ }^{4}$ Department of Clinical Biochemistry and Laboratories, Faculty of Medicine, \\ Tabriz University of Medical Sciences, Tabriz, Iran
}

(Received: 3 March 2015; accepted: 17 June 2015)

Interleukin-13 (IL-13) as a pleiotropic cytokine acts through the IL-13Ra1/ IL-4Ra complex to induce activation responses which contribute to the inflammatory diseases. Genetic polymorphisms in IL-13 and its receptor components have been proved to be associated with higher disease prevalence rates. Animal models such as in IL-13 deficient mice and transgenic animals also have been confirmed the critical role of this cytokine in the immune responses, mostly by IL-13 neutralization and IL-13/IL-4 dual neutralization strategies. This review highlights IL-13 structure as well as its pivotal roles in the normal physiologic and pathologic states. It is followed by a section on the recent findings on IL-13 receptors and signalling mechanisms to briefly summarize its functions in the immune systems. IL-13 roles in the human diseases such as asthma, systematic sclerosis, and some inflammatory diseases are described concisely. Finally some of the ongoing therapeutic applications are presented to comprehensively review IL-13 mediator roles.

Keywords: Interleukin-13, asthma, systemic sclerosis, gastrointestinal inflammatory diseases, anti-tumour immunity

*Corresponding author; E-mail: zbabaloo@tbzmed.ac.ir 


\section{Introduction}

Interleukin-13 (IL-13) is a cytokine secreted by activated T-helper 2 (Th2) cells. It is a counter-regulatory system for the type I immune response and has emerged as an important regulator of type II cytokine-mediated immune responses [1]. In the $80 \mathrm{~s}$, IL-13 was observed as a protein which is preferentially produced by activated mouse Th2 cells [2-4]. Several years later, three groups cloned the complementary DNA (cDNA) for human IL-13 [5-7].

IL-13 has a single open-reading frame with 132 amino acids. It contains a 20-amino-acidsignal sequence which is cleaved from the mature secreted protein. IL-13 is secreted as a 10-kd unglycosylated species [8] that has been demonstrated by the transfection of the cDNA into COS-7, i.e. the cells being CV-1 (simian) in origin, and carrying the simian virus 40 (SV40) genetic materials.

Crystallography technique allowed us to gain more information about the function of IL-13 and its receptors. By using this technique, IL-13 has been observed to have a $4 \alpha$-helical hydrophobic bundle core which is an indication of the class of type I cytokines and it has an up-up-down-down overall topology (Fig. 1) [9]. For a more detailed review on the structure of this cytokine (IL-13) refer to the paper by Eisenmesser et al. [10] (Fig. 1).

The gene encoding IL-13 is comprised of 4 exons and 3 introns and it is located $12 \mathrm{~kb}$ upstream of the gene encoding IL-4 on chromosomal region $5 \mathrm{q} 31$ (Fig. 2) [11]. Gene encoding IL-4 and IL-13 both are in the same orientation [12]. $5 q 31$ also contains the genes encoding IL-3, IL-5, IL-9 and granulocyte-macrophage colony-stimulating factor (GM-CSF)-4 and -12 . This chromosomal region has been linked with asthma [13-16] which we will discuss later. It is also worth mentioning that IL-13, IL-3, IL-5, IL-4, and colony-stimulating factor 2 (CSF2) form a cytokine gene cluster on chromosome 5q (Fig. 2).

IL-4 and IL-13 share many similarities yet they present some important differences. To name a few, IL-13 does not cause proliferation of T cells or differentiation of naive T cells towards Th2 cells as IL-4 does, and activation of mast cells by IL-13 is weaker than by IL-4 [8]. The 25-amino-acid hydrophobic structural core is completely conserved between IL-13 and IL-4, with only some conservative hydrophobic substitutions, however IL-13 only shares $25 \%$ homology with IL-4 at the amino acid level [18]. IL-4 contains 3 disulfide bridges and in contrast mass spectrophotometry revealed that L-13 contains only two bridges [19].

IL-13 has effects on immune cells that are similar to those of the closely related to IL-4. However, IL-13 is suspected to be a more central mediator of the pathophysiologic changes induced by allergic inflammation in many tissues. 

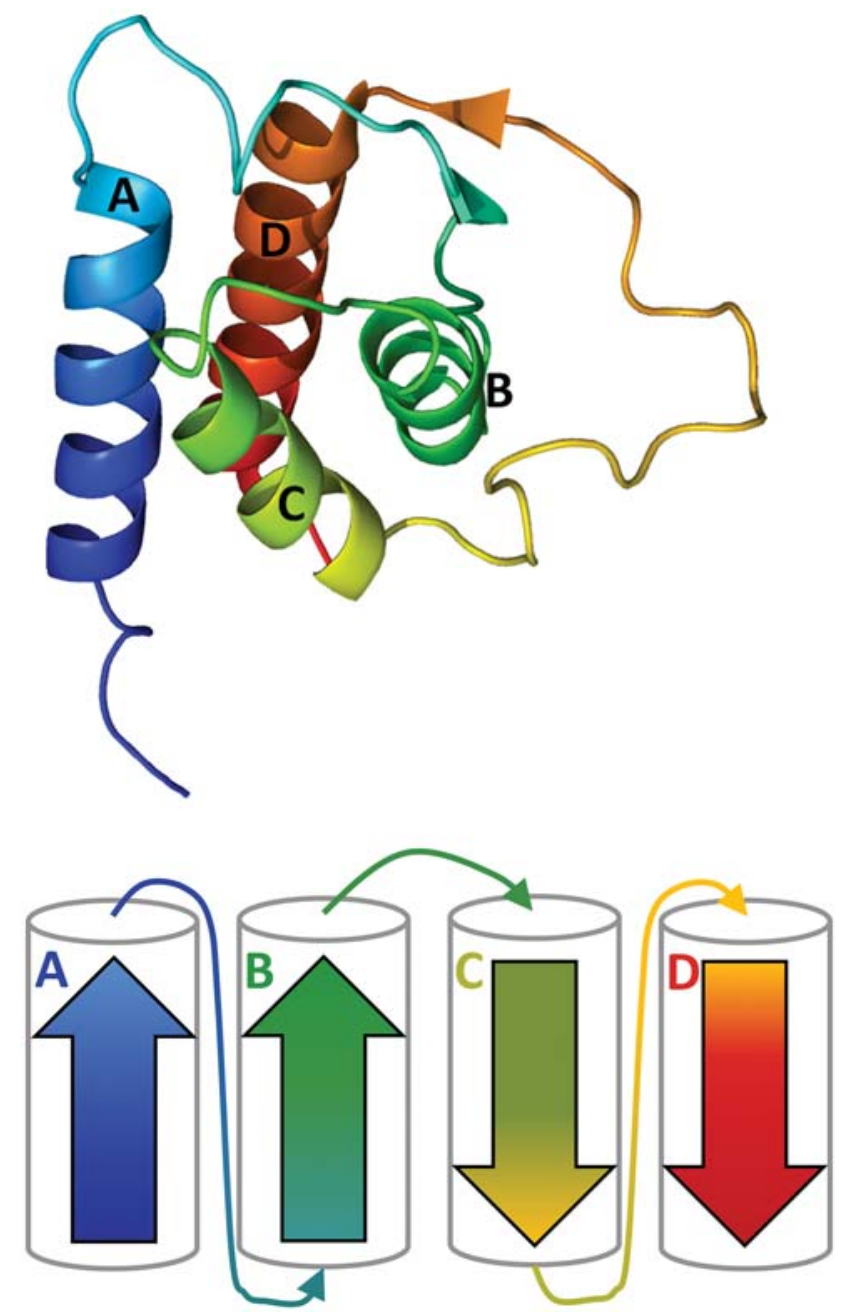

Figure 1. Top) Structure of IL-13 with a $4 \alpha$-helical hydrophobic bundle core which is an indication of the class of type I cytokines as rendered by Protein Data Bank in Europe (PDBe);

Bottom) The up-up-down-down overall topology of IL-13. Three loops connect four helical regions, i.e. A, B, C, and D together. A disulfide bond connects $\mathrm{AB}$ loop to BC loop.

$\mathrm{AB}$ and $\mathrm{CD}$ loops are connected by a short $\beta$-sheet which has not been shown in the figure [10]

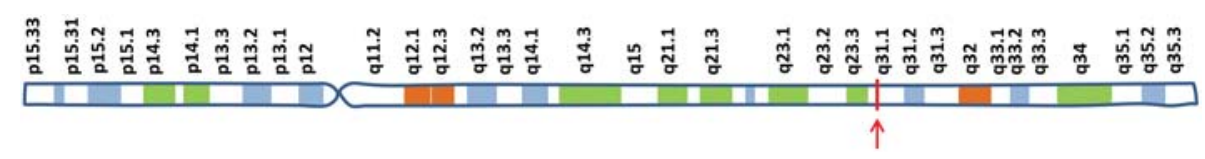

Figure 2. IL-13 Gene in genomic location. It is located $12 \mathrm{~kb}$ upstream of the gene encoding IL-4 on chromosomal region 5q31; Adapted from University of California Santa Cruz Genome Browser [11] 
Historically, researchers hypothesized that another ligand signalling through the IL-4 receptor complex was responsible for mediating the effector arm of the immune response. Therefore IL-13 was suggested as a plausible candidate player in the development of allergic airway responses due to a high degree of similarity between IL-13 and IL-4. Thereafter, it was demonstrated separately by two groups of researchers that specific blockade of IL-13 by administration of a soluble form of the IL-13Ra2 chain to allergen-challenged mice, in a way that only binds with IL-13 and not IL-4, reversed Airway HyperResponsiveness (AHR) and mucus production [20]. It also has been shown that acute administration of IL-13 itself was sufficient to recapitulate many features of the allergic phenotype, such as AHR, eosinophilic inflammation, and mucus cell hyperplasia in non-immunized mice or recombination-activating gene-deficient mice $[21,22]$.

IL-13 actions have been analysed both on the non-immune and immune cells with more focus on the former. IL-13 actions on resident cells in the bronchial tissues have been characterized with a focus on the involvement of IL-13 in the pathogenesis of bronchial asthma. Several studies demonstrated that IL-13 induces production of transforming growth factor beta (TGF- $\beta$ ) [23, 24], eotaxin-3 [25], and mucin [26]. It also has been shown that human and mice IL-13 induce calcium-activated chloride channel 1 (hCLCA1) and mCLCA3 (Gob-5) [27-31] in bronchial epithelial cells, respectively.

In addition, IL-13 has a wide range of roles on the fibroblasts inducing the expression of integrins [32], periostin [33] and proliferation [34]. It also has diverse functionality on the non-immune cells by inducing the production of eotaxin $[35,36]$ and enhancing contractility $[37,38]$ in bronchial smooth muscle cells. To mark the importance of the role of IL-13 in human disease we should note how its receptors function and what are the common signalling pathways and mechanisms. Following the next section we describe IL-13 role in Asthma, Systemic Sclerosis, Gastrointestinal Inflammatory Diseases (such as Ulcerative Colitis, Eosinophilic Oesophagitis, and Intestinal Fibrosis), and also its anti-tumour immunity role in sections $3,4,5$, and 6 , respectively.

\section{IL-13 receptors and signalling}

As mentioned, IL-13 is recognized as a type I cytokine and it signals through the type I cytokine receptors. Some of the well-known features of the type I cytokine receptors are the representation of four conserved cysteine residues, a W-S-X-W-S motif, fibronectin type II modules in the extracellular domain, and proline-rich box regions in the intracellular domain. The latest feature 
is important for binding of Janus tyrosine kinases (JAK) [9]. Despite no intrinsic kinase activity of these receptors they have constitutively associated with JAKs. This characteristic eventually results in the recruitment of downstream signalling molecules. Type I cytokine receptors recognize and respond to the cytokines with four $\alpha$-helical strands and they form heterodimers. In total, four receptors between IL-4 and IL-13 have been found so far, i.e. IL-4R $\alpha$, Type II IL-4R, Type II IL-13R, and IL-13R $\alpha 2$ that are described in the following sections.

$I L-4 R \alpha$

IL-4R $\alpha$ is a component of both type I and type II IL-4 receptors [17]. It is a $140-k d$ protein chain which binds IL-4 with high affinity and both IL-13 and IL-4 employ it as a component of their receptors. The cDNA of this chain encodes an open-reading frame of 825 amino acids $[39,40]$. The frame is contained a 25-amino-acid signal sequence. IL-4R $\alpha$ also shows type I cytokine receptorlike features with 4 conserved cysteines and the W-S-X-W-S motif in the extracellular domain.

It also contains a single transmembrane domain. A long intracellular domain is included in IL-4R $\alpha$ which contains a membrane proximal Box-1 sequence. This membrane serves as a docking site for JAK1 and 5 conserved tyrosine (Y) residues at positions Y497, Y575, Y603, Y631, and Y713.

Association of IL-4R $\alpha$ with the common $\gamma$ chain $(\gamma c)$, which is also a component of the receptors for IL-2, IL-7, IL-9 and IL-15 result in the type I IL-4 receptors [9]. The $\gamma c$ is important for the signalling of type I receptor however it does not bind neither with IL-4 nor with IL-13.

Studying the potent IL-4R $\alpha$ antagonists revealed that IL-4R $\alpha$ is also a component of the IL-13 receptor. These tested antagonists were observed to block IL-4R $\alpha$. Moreover, they were found to inhibit both IL-4 and IL-13 responses [41, 42]. Further studies demonstrated that both IL-4 and IL-13 responses can be inhibited by blocking antibodies against IL-4R $\alpha[43,44]$.

Type II IL-4R/IL-13R

The $\gamma \mathrm{c}$ has a significant role in the signalling of multiple cytokines and the mutated $\gamma c$ has been shown to cause several types of immunodeficiency in human [45]. IL-4 and IL-13 responses have been reported to remain intact even in the absence of $\gamma c$ in immunodeficiency patients [46]. These observations suggested 
that an alternate receptor for IL-4 and IL-13 might exist. Today this alternative receptor known to be comprised of IL-4R $\alpha$ and IL-13R $\alpha 1$, and it is a heterodimer. Although the $\gamma c$ is not a component of the type II IL-4/IL-13 receptor, there is some evidence that overexpression of the $\gamma c$ might affect IL-13 function [47]. Nonetheless the biologic relevance of this observation is unclear.

We should note that IL-13 has two cognate receptors: IL-13R $\alpha 1$ and IL-13R $\alpha 2$. They both are members of the haematopoietin receptor superfamily which share $37 \%$ homology at the amino acid level. In vitro expression has revealed that they both specifically bind IL-13 [48-51]. IL-13R $\alpha 1$ is a shared component between IL-13 and IL-4 and it serves as an alternative receptor for IL-4.

A 427-amino-acid sequence can be encoded by the proper cDNA for human IL-13R $\alpha 1$ where the sequence is comprised a 26 -amino-acid signal sequence. IL-13R $\alpha 1$ is a glycosylated protein with $65-$ to $70-\mathrm{kd}$ and it binds IL-13 with low affinity by itself. However when this cognate receptor paired with IL-4R $\alpha$ it binds IL-13 with high affinity [51]. Subsequently it forms a functional IL-13 receptor that signals effectively.

An imbalance can occur between IL-13R $\alpha 1$ and the $\gamma c$ for IL-4R $\alpha$ with overexpression of the $\gamma c$ by means of transfection. The imbalance could result in an increase of IL-4R $\alpha / \gamma c$ heterodimers and a compensatory diminishing of IL-13R $\alpha 1 / \mathrm{IL}-4 \mathrm{R} \alpha$ heterodimers. This response effectively reduces the IL-13 signalling. However, we should keep in mind that the $\gamma \mathrm{c}$ is not a component of the IL-13 receptor complex [52].

Although IL-4 and IL-13 are not the same in the term of species specific behaviour, yet IL-4R $\alpha$ and IL-13R $\alpha 1$ interact completely species specific. This has been evidenced by the fact that human IL-13R $\alpha 1$ could associate only with human and not mouse IL-4 $\alpha$ to form a functional receptor [53]. This species specificity is thought to allow some specific inhibition of IL-13 function without influencing the IL-4 signalling and that can be beneficial in the treatment of atopic disorders [54].

\section{$I L-13 R \alpha 2$}

The cDNA of human IL-13R $\alpha 2$ encodes a sequence frame of 380 amino acids. Despite the presence of IL-13R $\alpha 2$ transcripts in the brain, thymus, spleen, liver and lung $[55,56]$, this receptor is not required for the IL-13 functioning since the expression of both IL-13R $\alpha 1$ and IL-4R $\alpha$ is sufficient for administrating cells to respond to IL-13.

Although the expression of IL-13R $\alpha 2$ in vitro resulted in high-affinity binding of IL-13, it was insufficient even in the presence of IL-4R $\alpha$ to render re- 
sponsive cells to IL-13 [55]. IL-13R $\alpha 2$ has been found to frequently exist as an intracellular molecule in large colonies of IL-13R $\alpha 2$ in cultured monocytes, primary respiratory epithelium, respiratory epithelial cells, and primary human monocytes. These observations suggest the idea that this behaviour is not specific to a given cell type but rather it appears to be a widespread pattern [57].

After treatment of cells with interferon gamma (IFN- $\gamma$ ) the intracellular pools rapidly move to the cell surface. Based on this, a hypothesis has been proposed for IL-13R $\alpha 2$ role by which IL-13R $\alpha 2$ acts as a decoy receptor and it can regulate IL-13 responses. This has been supported by observing IFN- $\gamma$-dependent upregulation of IL-13R $\alpha 2$ that it was associated with diminished IL-13 signalling. This mechanism provides the evidence that IFN- $\gamma$ can regulate IL-13 responses. Although, some recent investigations have been reported that this receptor mediates IL-13 signalling under some circumstances which debates the concept of IL-13R $\alpha 2$ as a decoy receptor $[58,59]$. We should note that IL-4 and IL-13 receptors interact tightly and are likely under influence of similar triggers at various levels, although the confirmation of these similarities requires further investigations.

Finally, in spite of many similarities, IL-13R $\alpha 1$ and IL-13R $\alpha 2$ have different expression patterns on different cell types. IL-13 receptors are reported to be expressed on macrophages, human B cells, eosinophils, mast cells, endothelial cells, basophils, fibroblasts, monocytes, smooth muscle cells and respiratory epithelial cells. Different studies have supported the membrane-bound protein nature of IL-13R $\alpha 2$, however flow cytometry measurements highlighted IL-13R $\alpha 2$ predominantly as an intracellular molecule in different human cell types such as monocytes, airway fibroblasts, and bronchial epithelial cells [60]. The results of several studies reported that IL-13R $\alpha 1$ was expressed on several cells such as human skin fibroblasts, non-haematopoietic cells and monocytes [61]. It is also expressed on human Th17 cells but not on Th1 or Th2 cells [62] and is expressed on the M2 but not on the M1 subset of macrophages [63], which shows their diverse expression patterns on different cell types.

\section{IL-13 signalling}

IL-4 and IL-13 share common signalling pathways, consistent with the fact that they share common sub-units. IL-13 signalling uses the JAK-signal transducer (e.g. JAK1 and JAK3) and activator of transcription (STAT) pathway, specifically STAT6 which has been revealed by studying STAT6-deficient mice $[64,65]$. Figure 3 represents a schematic illustration of IL-4 and IL-13 receptors and signalling pathways. 


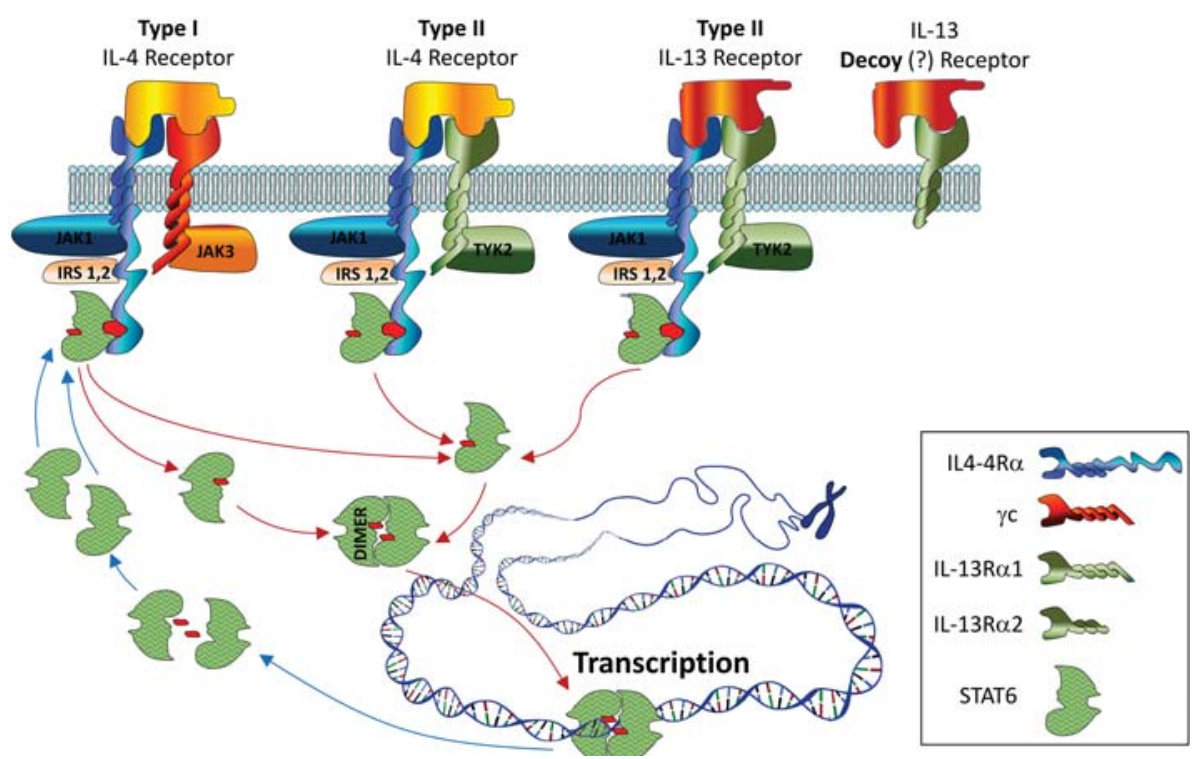

Figure 3. Schematic illustration of IL-4 and IL-13 receptors and signalling pathways. IL-4 and IL-13 share common sub-units and as a result they also share common signalling pathways. Adapted with permission from Hershey [61]

Stimulation of the complex by IL-4 and IL-13 result in the activation of signalling intermediates properties of IL-4 responses. This includes phosphorylation of IL-4R $\alpha$, insulin receptor substrate 2 (IRS-2), JAK1, and tyrosine kinase 2 (TYK2) [66, 67]. Consequently, signalling through IL-4R $\alpha / \mathrm{IL}-13 \mathrm{R} \alpha 1$ is thought to occur through IL-4R $\alpha$.

Five conserved tyrosine residues have been identified in IL-4R $\alpha$ : Y497, Y575, Y603, Y631, and Y713. They are all essential in signalling through this receptor. Y497 is part of the IL-4R motif that is necessary for the recruitment of insulin receptor substrate-1 (IRS-1) and IRS-2 to IL-4R $\alpha$ after IL-4 stimulation. Structure-function analyses also revealed its important role in IL-4-dependent cell proliferation [68]. Y713 is a part of an immunotyrosine-based inhibitory motif (ITIM). This tyrosine has been shown to be crucial in the negative regulation of IL-4 and IL-13 responses [69].

The rest of these tyrosines, i.e. Y575, Y603, and Y631, can act as STAT6 docking sites. They act in a way that as long as one of them remains intact, IL-4dependent gene induction remains intact too [70]. For a more detailed review on the similarities and differences between IL-13 and IL-4 receptors and signalling pathways refer to the paper by Callard et. al. [71]. 
As mentioned, despite many similarities between mouse and human IL-13 and their receptors, we should keep in mind the differences between those since most of the therapeutic attempts have been conducted on mice but we desire to apply them on humans. Here we briefly compare these genes and their receptors.

Structurally, human IL-13 is located on chromosome 5q31 but mouse IL-13 is located on chromosome 11 cytokine gene cluster [72]. Also both genes comprise four exons and three introns [73].

The hIL-13R $\alpha 2$ and hIL-13R $\alpha 1$ genes have been mapped to Xq24 [48] and $\mathrm{Xq13}$ [74], respectively. Human IL-13R $\alpha 2$ is consistent with a 26-amino-acid signal sequence and its mouse counterpart has 59\% shared amino acid identity [55] but both lack box-1 and -2 signalling motifs in their cytoplasmic domains. Although mice have $\mathrm{ng} / \mathrm{ml}$ serum levels of soluble (s) IL-13R $\alpha 2$, humans lack sIL-13R $\alpha 2$ in serum [75].

Finally, in spite of many structural characteristics similarities between IL-13 and IL-4, they have some important differences. Their ability to act across species is one of the most noticeable differences. IL-4 is absolutely species specific [18] while IL-13 is not [5, 8]. Human IL-4 acts only on human cells, and mouse IL-4 acts only on mouse cells. In contrast, mouse IL-13 acts on human or mouse cells with equal potency. Although IL-13 is believed to be species selective because human IL-13 has greater activity on human cells than on mouse cells.

In the previous sections we summarized the general characteristics, functions, receptors, and signalling of IL-13. Following sections are aimed to briefly cover some of the human diseases that are highly influenced by this interleukin.

\section{IL-13 in asthma}

Bronchial asthma is a chronic inflammatory disease which is a complex disorder and has not yet been fully understood. While it has been recognized since ancient Egypt, its incidence, morbidity, and mortality have been increasing very rapidly in industrialized countries within the last few decades [76].

Wheezing, breathlessness, chest tightness, and coughing are the frequent episodic symptoms of asthma. It has been shown that a variety of stimuli, such as allergens (e.g. molds, house dust mites, and plant and animal debris), pharmacological agents (e.g. aspirin), infectious stimuli (e.g. particularly viruses), and airborne pollutants (e.g. ozone and diesel exhaust particles) and irritants (e.g. tobacco smoke) can trigger the above-named symptoms. The presence of lym- 


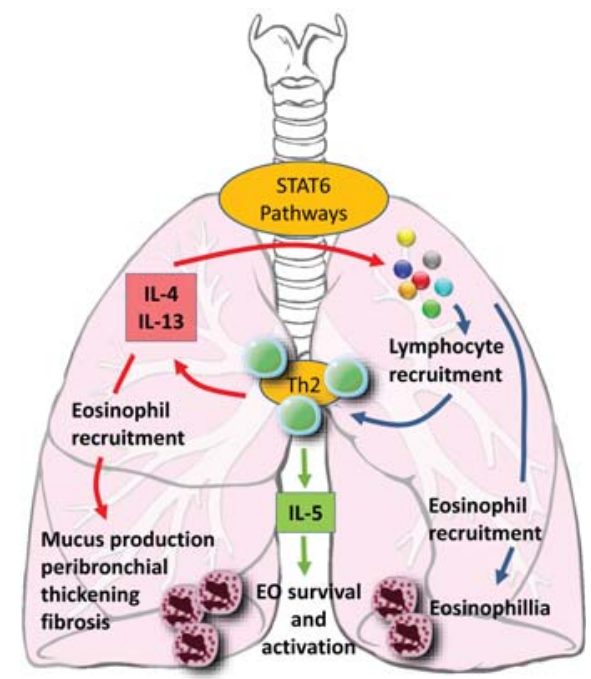

Figure 4. Schematic illustration of the Th2 cytokines' IL-4- and IL-13-induced responses. They induce the production of specific cytokines through STAT6 signal-activated pathways. Adapted with permission from Lukacs et al. [82]

phocytes, eosinophils, and mast cells, along with epithelial desquamation, goblet cell hyperplasia, and thickening of the submucosa have been associated with the main physiologic abnormalities of the disease, namely airway obstruction and AHR [20, 77, 78].

The disease is thought to be caused by aberrant T-lymphocytes when it responds to non-infectious environmental antigens. The existence of activated Th2 cytokine producing cells in the airway wall is recognized to be one of the important symptoms of asthma. Each of the Th2 cytokines (such as IL-4, IL-5, IL-9, and IL-13) likely contributes to the overall immune response directed against environmental antigens. In particular, the role of IL-13 in the regulation of the allergic diathesis has been well established by conducting initial studies in animal models of the disease. These studies provided strong evidences that IL-13 was both necessary and sufficient to cause all the known features of allergic asthma. This role of IL-13 was confirmed to be independent of the role of other Th2 cytokines.

Variety of investigations on humans and animal models of allergic disease support the essential role of Th2 cytokines in the pathogenesis of allergic asthma. For instance $\mathrm{CD}^{+} \mathrm{T}$ cells that produce a Th2 cells' pattern of cytokines [IL-4, IL-5, and IL-13] has been hypothesized to contribute significantly in the pathogenesis of disease [79-81]. Figure 4 schematically shows the Th2 cytokines' IL-4- and IL-13-induced responses. 
Early investigations were aimed to understand the role of IL-4, as a paradigmatic cytokine, in Th2 differentiation and in regulation of the synthesis of the reaginic antibody IgE. Results of these experiments on IL-4-deficient mice supported that the presence of IL-4 for the development of allergic symptoms is essential as no phenotype was observed in allergen-challenged IL-4 knockout (KO) mice [83]. These studies suggested while IL-4 is not critical for the effector phase of the response it is essential for the initial development and expansion of antigen-specific Th2 polarized cells $[84,85]$. It was then hypothesized that another ligand signalling through the IL-4 receptor complex was responsible for mediating the effector arm of the immune response, and IL-13 was suggested as a plausible candidate player in the development of allergic airway responses.

It was demonstrated separately by two groups of researchers that specific blockade of IL-13 by administration of a sIL-13Ra2 chain (i.e. a soluble form of the IL-13Ra2 chain) to allergen-challenged mice in a way that binds only IL-13 (and not IL-4) reversed AHR and mucus production. In addition to this demonstration, it was shown that acute administration of IL-13 was sufficient to recapitulate many features of the allergic phenotype, such as AHR, eosinophilic inflammation, and mucus cell hyperplasia in non-immunized mice or recombination-activating gene-deficient mice [21, 22].

These features were recapitulated by targeted pulmonary overexpression of IL-13 in the murine lung, and the subepithelial fibrosis and the formation of Charcot-Leyden crystals were observed as well [86]. Allergen-induced AHR was reported to occur in the absence of IL-13 but it was not evident in the double IL-4/IL-13 KO mice [87]. Thereafter, a study (that conducted with the same IL-13 $\mathrm{KO}$ mice) provided a conclusive evidence of the crucial role of IL-13 in mediating allergen-driven AHR and mucus hypersecretion [88]. All these observations support the idea that IL-4 is essential for the initiation of Th2 polarized immune responses to the allergenic peptides, while IL-13 alone may mediate the main physiological consequences of the disease.

The field has made great progress in understanding how influential Th2 cytokine directs airway remodelling, airway inflammation, and asthma pathogenesis and IL-13 is recognized as a central mediator of human asthma [89, 90]. This role has been supported by showing that IL-13 polymorphisms, such as G+2044A [e.g. 91, 92], C-1112T [e.g. 93], and A-1512C [e.g. 92, 94], are strongly associated with asthma susceptibility [95] (see the review by Vercelli [96] for more details) and by finding that many IL-13-induced pathways are associated with asthmatic airway responses [97]. IL-13 and IL-4 activate STAT6 since they both share the IL-4R $\alpha$ subunit in their receptors [98]. In addition, STAT6 activation is crucial for the differentiation of T-cells into Th2 effector cells [99]. It regulates IL-13- and IL-4-induced production of Th2 cytokines such as eotaxin, 
smooth muscle cells and fibroblasts [100]. Therefore, the IL-13/IL-4/STAT-6 pathway has been proved to be a prominent player in asthma pathogenesis [89]. For a more detailed review on the role of IL-13 and its pathway and signalling in asthma and allergic disease read the paper by Ingram and Kraft [89].

\section{IL-13 in systemic sclerosis}

Systemic sclerosis ( $\mathrm{SSc}$, scleroderma) is an autoimmune disease or connective tissue disease which is characterized by vascular damage, inflammation and progressive fibrosis of several internal organs and patients' skin [101]. At the present time, it is unknown what causes SSc. However it has been shown that genetic, environment and abnormal immune function influence SSc prevalence, incidence, and progression that are subjects of active investigations [102, 103]. The prevalence of SSc is estimated to be 2 to 3 per 10,000 individuals in the USA and it is at a higher rate in the industrial countries [104].

The most prominent clinical signs of SSc is tissue fibrosis. It is believed to occur due to a reactive process which is likely a result of extracellular matrix (ECM) components overproduction [105]. The activation of ECM is thought to be a response to inflammation, autoimmune attack and vascular damage. Through this process T cells play a significant role in the pathogenesis of SSc. They derive some cytokines that implicate in the reparative inflammatory and fibrotic processes of SSc [102]. The serum and tissue of SSc patients show abnormal levels of these cytokines. They are involved in the different stages of the disease. For example, Th1 and Th17 cytokines are involved in the inflammatory processes [106]. In addition, Th2 cytokines are considered profibrotic, and IL-13 plays significant role in the pathogenesis.

Figure 5 illustrates how IL-13 can participate in the pathogenesis of SSc through different mechanisms. IL-13 is heavily implicated in the effector phase of inflammation and fibrosis. It involves both directly and indirectly in the fibroblast activation and stimulation of TGF- $\beta$, respectively [107]. The latter occurs by stimulation of macrophages to produce TGF- $\beta$ which includes several distinct mechanisms such as the production of latent TGF- $\beta$ and up-regulation of MMPs that cleave the LAP-TGF- $\beta$ complex $[108,109]$, and via an IL-13Ra2 signalling pathway [110] (Figure 5).

The importance of IL-13 in SSc is also supported by several other investigations $[110,112,113]$. For example Hasegawa et al. reported that SSc patients had higher serum levels of IL-13 compared to the control group and this higher expression of IL-13 was correlated with C-reactive protein levels and erythrocyte sedimentation rates. They concluded IL-13 could be one of the cytokines which 


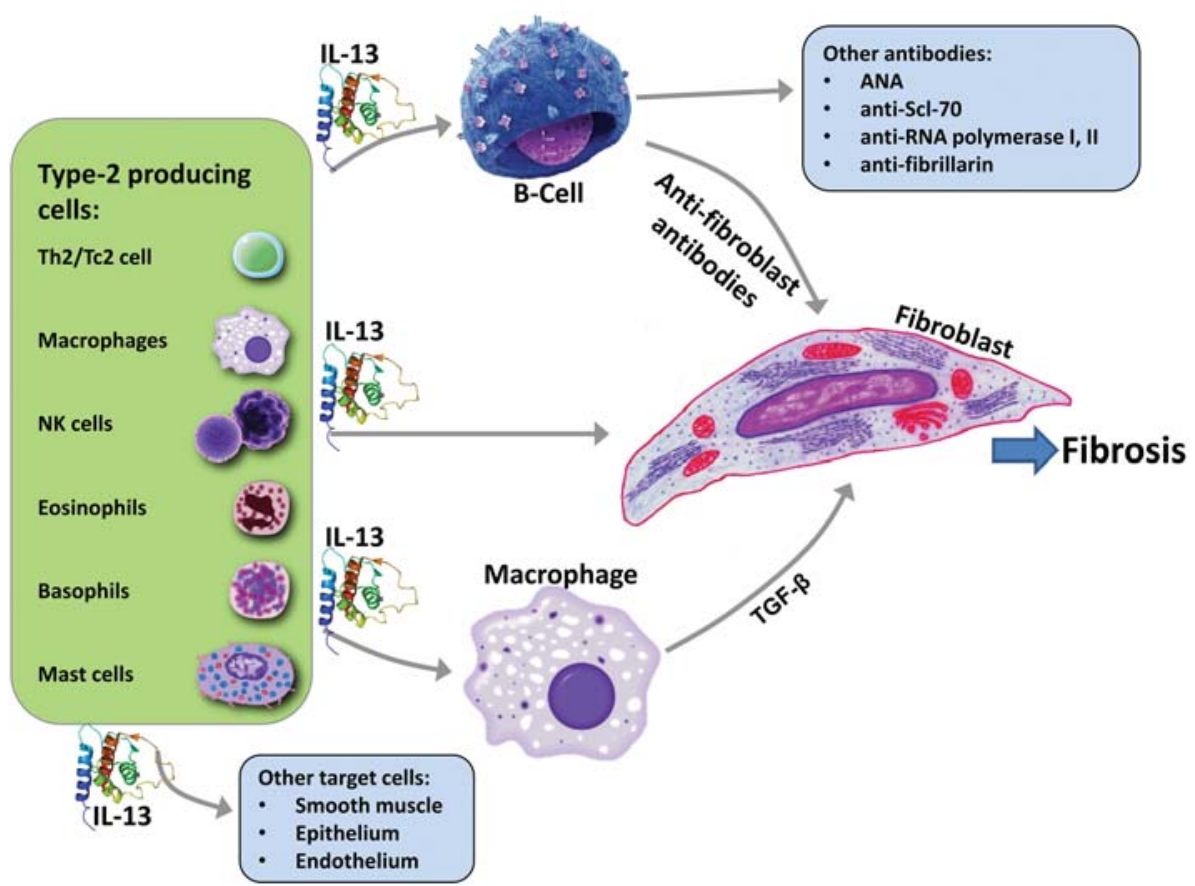

Figure 5. IL-13 plays significant role in systemic sclerosis pathogenesis by several different mechanisms. It is heavily implicated in the effector phase of inflammation and fibrosis. It involves both directly and indirectly in the fibroblast activation and stimulation of TGF- $\beta$, respectively. Adapted with permission from Fuschiotti [111]

contribute to the disease progression $[114,115]$. More recently Fuschiotti et al. found that peripheral blood effector $\mathrm{CD} 8^{+} \mathrm{T}$ cells from SSc patients show a shift toward a type 2 phenotype. This shift is determined by up-regulation of IL-13 which correlates with the extent of skin fibrosis [116]. They also found that the level of IL-13 production compared to $\mathrm{CD}^{+} \mathrm{T}$ cells is lower and it is more variable $[116,117]$. This difference suggests that dysregulated IL-13 production is more a feature of $\mathrm{CD} 8^{+}$rather than $\mathrm{CD} 4^{+} \mathrm{T}$ cells in $\mathrm{SSc}$. However the role of $\mathrm{CD} 8^{+}$ $\mathrm{T}$ cells in SSc is not well understood since most studies have been focused on $\mathrm{CD} 4^{+} \mathrm{T}$ cells so far. Lack of a comprehensive study on $\mathrm{CD} 8^{+}$is mostly due to the strong MHC class II HLA association with certain forms of the disease and the presence of distinct and specific autoantibodies [118, 119].

Polymorphisms in the genes for IL-13 [110] and IL-13Ra2 [110] likely increase the susceptibility to SSc. The single nucleotide polymorphism (C to T exchange) in the promoter of the IL-13 gene has been found to be associated with SSc in a cohort of Caucasian population [110]. Relatively few factors have been 
shown to regulate the IL-13 transcription and among them GATA-3 is recognized to be the most important factor regulating IL-13 gene expression [120-124].

GATA-3 is reported to effectively activate the proximal IL-13 promoter and a putative GATA-3 binding site identified to contain therein [125]. Defects in the molecular control of IL-13 production are likely to play an important role in the pathogenesis of diffuse cutaneous SSc [126]. Analyzing the extracted GATA-3 from the freshly isolated naïve $\mathrm{CD}^{+} \mathrm{T}$ cells from SSc patients shows a significantly higher level in comparison to the control group. Up-regulation of GATA-3 expression has also been demonstrated in the transcriptional profiling of peripheral blood cells from early SSc patients [127]. Another role of GATA-3 in the regulating IL-13 expression has been observed when silencing of GATA-3 with siRNA significantly reduced GATA-3 and IL-13, but IFN- $\gamma$ levels in CD ${ }^{+}$T cells from SSc patients remained invariant [126].

Moreover, the GATA-3 expression and functions have shown to be controlled by multiple factors [128] including the Th1-specific transcription factor T-bet. This factor induces IFN-c production [129-131] and inhibits Th2 cytokines such as IL-13 [132, 133], by antagonizing GATA-3 expression and/or function [134]. The Th1/Th2 polarization is believed to be determined by the mutually exclusive expression of T-bet and GATA-3 [1]. T-bet polymorphisms have shown to be associated with increased risk of SSc [135]. More recently, IL-33 was found to stimulate mouse bone marrow-derived eosinophils to secrete IL-13 and promote cutaneous fibrosis [113]. According to these observations the IL-13 overproduction in SSc may result from excess IL-33 stimulation. These findings suggest that the molecular control of IL-13 production by $\mathrm{CD}^{+} \mathrm{T}$ cells is abnormal in $\mathrm{SSc}$ patients. It is also believed to be critical for predisposing patients to more severe forms of the disease. Subsequently GATA-3 overexpression is likely one of the most important drivers in the pathogenesis of SSc.

\section{IL-13 in gastrointestinal inflammatory diseases}

As mentioned IL-13 is a cytokine that is recognized mostly by its roles in the allergic and other inflammatory diseases [136]. The main inflammatory role of this cytokine is against helminthic infections as a part of the gut mucosal immune response system. IL-13 acts in mucosal immunity as a factor that stimulates goblet cells to produce mucus, attracts eosinophils by local eotaxin to release and increase the IgE production. In addition, IL-13 has a possible contribution to increase gut motility and epithelial secretion $[137,138]$.

IL-13 KO mice show more durable parasite expulsion times following the experimental intestinal nematode infection [139, 140]. IL-4R $\alpha$ and STAT6 defi- 
cients show a similar pattern but IL-4 deficient mice do not follow the pattern. These observations led to this conclusion that IL-13 likely has significant role in antihelminth immunity. In addition, CD4 cells from Trichuris muris infected wild-type mice are frequently reported to be able to transfer resistance to infection in T and B cell deficient (SCID) mice [141]. Therefore it is believed that CD4 $\mathrm{T}$ cells are the major source of gut mucosal IL-13 in helminth infections.

IL-13R $\alpha 1$ also can be found constitutively in gut epithelium. However it is remained unanswered whether IL-13 always plays a significant homeostatic role or this cytokine only acts in infection and/or injury. On one hand, IL-13 limits Th17 inflammation by blocking IL-17 production which is a subsequent result of increasing IL-10. This effect has been proved by investigating related responses on both human and mouse cells which suggests a homeostatic role of IL-13 in the gut [142]. On the other hand, IL-13 may play an important role in limiting evolving colitis injury. Through this process IL-10 KO mice are susceptible to severe $\mathrm{T}$ muris gut infection. This occurs when the IL-13R $\alpha 2$ decoy receptor is also deleted which effectively increases the bioavailability of IL-13. Therefore mortality and induction of colitis increase the protection significantly [143, 144].

We should note here that IL-13 has been stated as a component of various types of mucosal inflammation. This includes ulcerative colitis and eosinophilic oesophagitis (EO) in addition to allergic asthma, and many other diseases bearing fibrosis [136] that we briefly cover in the following sections.

\section{Ulcerative colitis}

IL-13 is known as an effector cytokine that drives inflammation in ulcerative colitis. This role has been shown by using a suit of murine models of ulcerative colitis from confirmed excess production of IL-13 in human disease [145]. A consequence of increasing the hallmark cytokine of the Th2 response (IL-4) is a significant increase in the produced IL-13 by lamina propria mononuclear cells. The lesion can be prevented effectively by depleting NKT cells and also by administration of an IL-13R $\alpha 2-\mathrm{Fc}$ fusion protein. Therefore the NKT cells are the major source of the IL-13 that contributes to the inflammation [146].

Administration of intratracheal $\alpha$-galactosylceramide analogue in mice leads NKT cells to induce a Th2 inflammatory response (i.e. IL-4, IL-5 and IL-13) to the other antigens. This induction suggests that NKT cells are important components of innate IL-13 responses [147]. IL-13 level in patients with active ulcerative colitis is higher which is resulted from lamina propria mononuclear cells. They also have shown increased epithelial pSTAT6 in comparison to the active Crohn's patients and healthy controls [148, 149]. 
The deleterious effects of IL-13 on the epithelial barrier and colonic epithelial cells occur when the production of IL-13 in ulcerative colitis is extremely high. IL-13 has been reported to activate the proapoptotic molecule cysteineaspartic acid protease 3 (CASP3) in mouse colonic epithelial cells as well as in patients with active ulcerative colitis [150]. In vitro studies show that IL-13 can induce epithelial cell apoptosis and it also causes disruption in tight junction by inducing claudin 2 [151]. These observations support the idea that IL-13 is a potentially valuable target for therapeutic objects in ulcerative colitis.

\section{IL-13 in eosinophilic oesophagitis}

Eosinophilic oesophagitis (EO) is a disease characterized by infiltration of the oesophageal mucosa with allergic inflammatory like conditions [152]. The role of IL-13 in the induction of typical lesion of EO is demonstrated by investigating the animal models. For instance, subsequent eosinophilia of the oesophagus after nasal or tracheal administration of IL-13 was observed in the animal models [153], and aeroallergen induction of an EO-like lesion, in both IL-13 and STAT6 deficient mice, failed to develop the oesophageal inflammation [154]. Similarly, induction of IL-13 overexpression in the lungs resulted in the oesophageal eosinophil infiltration and oesophageal tissue remodelling [155]. Murine oesophageal tissue, after incubation with IL-13, produces several factors that are important in the development of EO [156]. Clear cytokine profile in EO indicates significant upregulation of IL-13 and IL-5 expression [157]. Elevated levels of IL-13 and IL-5 are also reported to be detectable in the plasma of children with food allergy and EO [158].

Although these evidences of the existence of correlation between IL-13 and the development of EO are significant but further investigations are required to comprehensively understand the underlying mechanisms by which we are able to link the IL-13 to the related diseases.

\section{IL-13 in intestinal fibrosis}

Tissue fibrosis such as hepatic fibrosis [159], progressive systemic sclerosis $[115,160]$ and idiopathic pulmonary fibrosis [161] are deleterious outcomes of IL-13 exposure. This has been proved by demonstrating the relation between tissue remodelling with animal models of EO, bleomycin induced pulmonary fibrosis [162] and allergic asthma [86, 155]. A massive IL-13 production has been observed in the 2-, 4- and 6-trinitrobenzenesulfonic acid (TNBS) model of colitis after administration of TNBS in the examined mice. 
Scharl et al. reported IL-13 induces genes involved in cell invasion that lead to fistula formation through tissue [163]. It has been also confirmed that TGF $\beta$ highly expresses and induces IL-13 by lamina propria fibroblasts. Taken all these observations together it can be concluded that IL-13 is likely an important target for antifibrotic therapies in specific settings [164].

\section{IL-13 in anti-tumour immunity}

In the last decade many researches have been conducted to understand mechanisms by which cancer cells evade the immune system. It is mostly believed that immune deviation toward Th1 response, including activation of $\mathrm{CD} 8^{+}$ cytotoxic T cells (CTLs), results in tumour rejection whereas divergence toward Th2 response prevents tumour rejection [165]. Anti-tumour immunity via Th1 and CTL is down-regulated in different ways in tumour-bearing animal models and cancer patients. Since immune deviation toward Th2 suppresses Th1-activation, it is believed that induction of a Th2 immune response is one of the mechanisms that negatively affect tumour immune responses. IL-13 as a Th2 secreted cytokine plays a critical role in many aspects of immune regulation. IL-13 has central role in immunoregulatory pathway in which NKT cells suppress tumour immunosurveillance [166].

\section{IL-13 in negative regulation of immunosurveillance}

Several mechanisms are thought to be responsible for the immunosuppression by diminishing Th1-responses such as DTH or CD8 ${ }^{+}$CTL activity in cancer cases. One hypothesized mechanism is to skew immune response against tumour toward Th2 suppresses Th1 immune responses. Researches have been investigating experimental methods to establish this hypothesis. A frequently used experiment is studying STAT6-deficient mice. In this experiment, STAT6 $\mathrm{KO}$ mice (that are deficient in IL-4R $\alpha$-mediated signalling) showed tumour regression that demonstrates a tumour supportive role for IL-13 and/or IL-4 [167-169].

IL-4R $\alpha$ KO and STAT6 KO mice have been observed to reject the tumours but IL-4 KO has not been reported to act similarly. This implies the significant immunosuppressive role of IL-13 as a tumour immunosurveillance inhibitor in comparison to IL-4. Inhibiting of IL-13 by soluble IL-13R $\alpha 2-\mathrm{Fc}$ leads to the tumour rejection in both IL-4 KO mice and wild-type mice. Therefore IL-13 is likely to be the dominant cytokine which negatively regulate CTL-mediated 
tumour immunosurveillance. In addition, NKT cell-deficient CD1d KO mice after tumour induction are highly resistant to the tumour and consequently IL-13 production by $\mathrm{T}$ cells would be reduced significantly. This experiment supports results from another study which reported CD4 ${ }^{+}$NKT cells from tumour-bearing mice showed up-regulated IL-13 production.

Both experiments which we gave here as examples indicate that $\mathrm{CD}^{+}$ NKT cells act as the dominant source of IL-13, and CD4 ${ }^{+} \mathrm{T}$ cells produce very low levels of IL-13 in tumour bearing mice. They concluded that the IL-13 produced by $\mathrm{CD}^{+} \mathrm{NKT}$ cells down-regulates $\mathrm{CD} 8^{+} \mathrm{CTL}-$ mediated tumour immunosurveillance through the IL-4R $\alpha$-STAT6 pathway [169]. However, one may speculate how IL-13 represses CTLs since T cells do not express type II IL-4 receptors, although they express the type I IL-4R.

New findings are consistent with the speculation that IL-13 from NKT cells activates $\mathrm{CD} 11 \mathrm{~b}^{+} \mathrm{Gr}-1^{+}$myeloid cells to produce TGF- $\beta$ in tumour-bearing mice, and it acts directly on $\mathrm{CD}^{+} \mathrm{T}$ cells to negatively regulate tumour-specific CTL [170]. This down-regulation of tumour immunosurveillance by IL-13 also has been observed in a colon carcinoma lung metastasis model, in which tumour development was partially inhibited in CD1d $\mathrm{KO}$ mice and mice treated with IL-13 inhibitor, but has not been observed in IL-4 KO mice [166].

Along with these findings, by studying fibrosarcoma and colon carcinoma an experiment on the orthotopic breast tumour model with lung metastasis revealed that STAT6 KO mice and NKT cell-deficient CD1d KO mice are highly resistant against lung metastasis [171]. It has been reported that IL-13inhibitor treatment of HER-2/neu transgenic mice can delay the progression of spontaneous autologous mammary carcinomas [166]. These data collectively confirm this notion that negative regulatory pathway by NKT cells and IL-13 inhibits immunosurveillance against different types of tumours and also blockade of this pathway may intensify the efficacy of anti-tumour vaccines in the future $[172,173]$. In contrast to these observed roles, which introduce IL-13 as a cytokine that modulates adaptive immune responses, there are some indications that show local delivery of IL-13 at the tumour site induces tumour regression or rejection mediated by granulocytes and macrophages [174, 175].

\section{Direct effects of IL-13 on tumours}

In addition to these indirect effects of IL-13 on tumours it could affect tumours directly as well. Type II IL-4R is expressed on a wide range of cells included tumour cells. Several indications of type II IL-4R on tumour cells have 
been reported including lymphoma [176], renal cell carcinoma, glioblastoma [177], head and neck cancer [177, 178], hepatoma [179], pancreatic cancer, breast cancer [174], prostate cancer [180], and colon cancer [181]. Among them the role of IL-13 and its receptor is more studied in Hodgkin's lymphoma/Reed-Sternberg cells (H/RS) [182]. According to these studies IL-13 in H/RS cells acts as an autocrine growth factor in vitro and IL-13 blocking shows signs of apoptosis induction [183]. In addition, the H/RS cell lines have been observed to activate STAT6 which implies the presence of signal transduction through the receptor. These observations were made in both in vitro in tumour cell lines and in vivo by examining biopsies of H/SR [184]. The expression of IL-13 and phosphoSTAT6 is exclusive to H/RS and not to the other types of lymphoma. IL-13 production by H/RS may also affect the immune response to the tumour in addition to its autocrine effect [185].

One of the other mechanisms of triggering tumour metastasis is the reduction of cell-cell adhesion. In the colon cancer cell line, which expresses the type II IL-4R, both IL-4 and IL-13 negatively regulate the expression of two molecules that are responsible for the cell adhesion, i.e. E-cadherin and carcinoembryonic antigen [181]. In some occasions IL-13 up-regulates VCAM-1 which is observed in the glioma cell lines which expresses IL-4R $\alpha$, IL-13R $\alpha$, and IL-13R $\alpha 2$ [186]. IL-13 also directly acts on B chronic lymphocytic leukaemia (B-CLL), however IL-13 does not act as a growth factor as similar as in H/SR but rather it inhibits IL-2-induced proliferation and apoptosis [176]. In summary, by several mechanisms, IL-13 can promote survival of certain types of tumours through direct action on the tumour or acting through suppression of immunosurveillance.

Here we briefly summarized the importance of IL-13 only in some of human diseases, but various studies have shown that IL-13 probably has much wider influence on variety of human diseases. To name a few, we [187] reported IL-13 was present in serum from patients with active primary visceral leishmaniasis (VL). They indicated that IL-13 serum level drops to control level after successful treatment. Chen et al. [188] suggested that IL-13 C-1112T promoter polymorphism is associated with the risk of chronic obstructive pulmonary disease (COPD) in Arabian population by conducting a meta-analysis. More recently, we showed significant association of IL-13 polymorphisms with Multiple Sclerosis (MS) in Iranian patients [189]. We concluded that both promoter and coding regions of IL-13 gene affect susceptibility to MS.

Although, enormous evidences have been presented to support crucial role of IL-13 gene in variety of human diseases but further investigations are required to prove it, especially in non-allergic diseases. 


\section{Therapeutic applications}

After reviewing some of the important roles of IL-13 in human diseases it naturally follows to use this interleukin for therapeutic purposes. This paradigm has been extensively developed since IL-13 was discovered 28 years ago [4]. For instance, early attempts show IL-13 blockade by sIL-13R $\alpha 2-\mathrm{Fc}[21,22]$ or by antibody [190] in murine systems limits asthmatic responses. The limitation of asthmatic responses includes but not limited to AHR, eosinophilia, mucus production, IgE generation, and fibrosis. Based on this limiting act several monoclonal antibodies, that targeting IL-13, are being developed for the treatment of asthma and several more are expected to be developed after preclinical development stage [191-193].

Airway challenge with Ascaris antigen triggers early and late phase bronchoconstriction responses in sheep sensitized to the nematode parasite. Airway hyperresponsiveness to carbachol also has been observed. To protect the animals from the late phase bronchoconstriction (following airway challenge with Ascaris antigen, and inhibit Ascaris-induced airway hyperresponsiveness) we may apply human IL-13 antibody IMA-638 (a.k.a. Anrukinzumab). This antibody should be delivered by intravenous infusion 24 hours prior to antigen challenge [194]. Early Anrukinzumab delivery reduces the inflammatory infiltrate [195]. It can also significantly reduce the early phase response when the usage of the antibody is at high dose [194]. In cynomolgus monkeys Ascaris-sensitizing shows manifestations such as that segmental lung challenge with the antigen induces an eosinophilic airway inflammation.

Therapeutic applications of IL-13 were progressed by finding several new peptide-based vaccines for IL-4 and IL-13. They have been developed and utilized in mouse asthma models. Crystallization of the IL-4/IL-4R $\alpha$ revealed its detailed structure and it has been suggested a peptide epitope of IL-4 that lies at the contact site with IL-4R $\alpha$. The peptide was conjugated to truncated hepatitis B core antigen as carrier. This vaccine raised high titers of IgG to IL-4 which consequently led to reduction in IgE antibodies to ovalbumin (OVA), bronchoalveolar lavage fluids (BAL F) inflammation, AHR to methacholine [196].

In order to produce peptide-based vaccine for IL-13 a similar method was used and mice were immunized by applying a peptide corresponding to a phylogenetical region which is believed to contain a receptor interaction site. The IL-13-immune mice demonstrated reduced IgE titres, airway inflammation, mucus metaplasia, and AHR to methacholine after OVA immunization and challenge [194]. All these observations suggest that in mice, asthmatic responses can be well controlled by the presence of antibody to either IL-4 or IL-13. 


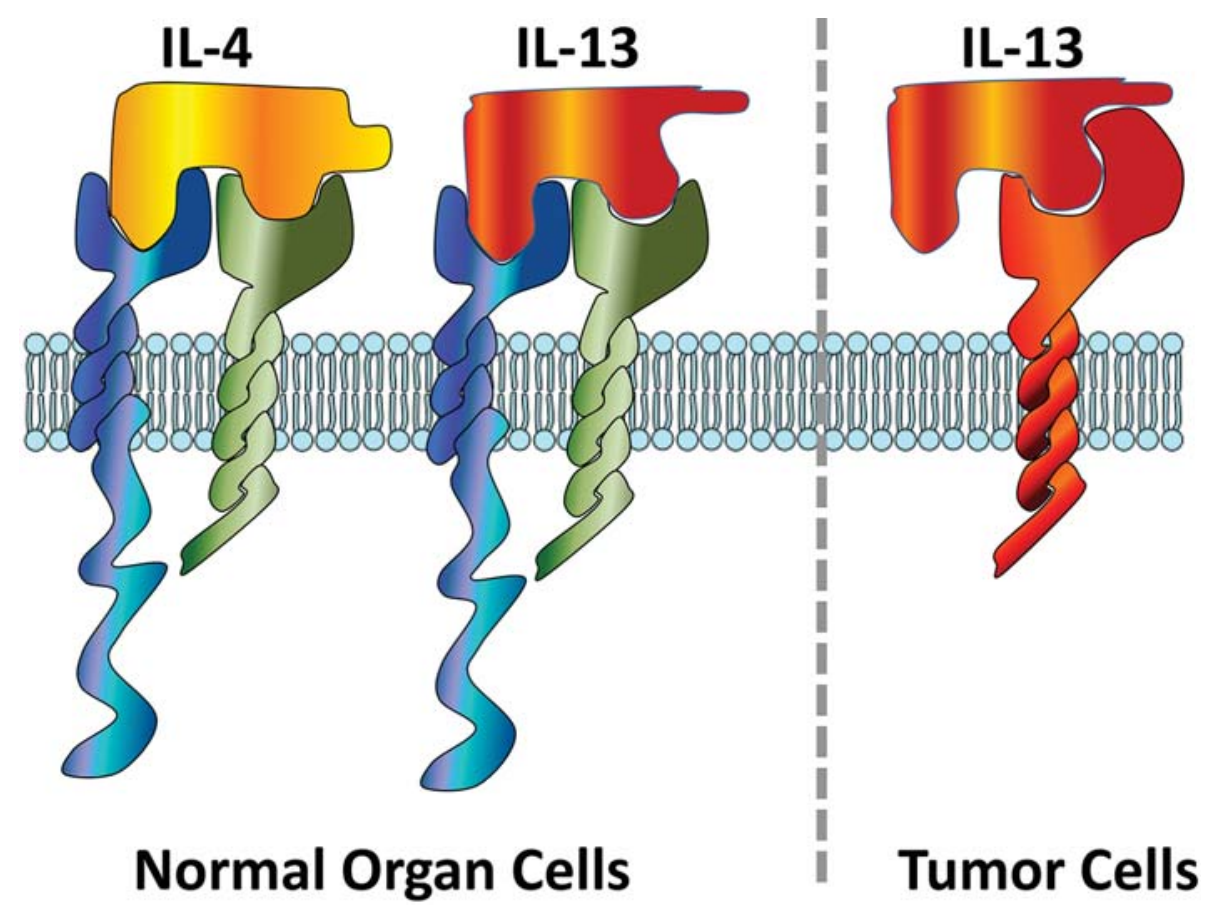

Figure 6. Mutated IL-13 based compound binds IL-13 receptors more tightly than normal tissue IL-13 receptors in high-grade astrocytomas [198, 199]. This compound does not bind normal cell receptors which promises more restrictive IL-13 receptors that can be expressed on cancer cells

Although these experiments were all on mice but several companies have already started clinical trials with the Food and Drug Administration's (FDA) approval, achieving Fast Track designation and have been conducted successful clinical trials. As an example, one of these researches has been based on a new finding about IL-13 which high-grade astrocytomas (i.e. the deadliest form of brain cancer and perhaps the most prevalent one) overexpress IL-13 receptors significantly higher than its level in normal tissue [197, 198]. Debinski et al. [197] developed mutated IL-13 based compounds which bind IL-13 receptors more tightly than normal tissue IL-13 receptors in high-grade astrocytomas (Fig. 6). In addition, the discovered compounds do not bind normal cell receptors. This behaviour directs towards more restrictive IL-13 receptors which can be expressed on cancer cells.

These advances are believed to help the treatment of brain cancer from different aspects [199]. First, by combining the targeting molecule, i.e. a mutated IL-13, with a cellular toxin it would be possible to make a "smart bomb" which delivers the cytotoxin that is specific to cancer cells. Second, by attaching a ra- 
Table I. Summarizing some of the findings in IL-13 therapeutic applications in asthma which led to the first successful clinical trial with IL-13/IL-4 inhibitor by applying a random-access, cross-disciplinary approach. Partially adapted from Grunig et al. [200]

\begin{tabular}{|c|c|c|c|}
\hline & Animal Models & $\begin{array}{c}\text { Cell Culture \& Molecular } \\
\text { Biology }\end{array}$ & Clinical Studies \\
\hline \multirow{4}{*}{$\begin{array}{l}\hat{\infty} \\
\cong\end{array}$} & Expression in Th2 responses & Cloning of IL-13 & Expression in asthma \\
\hline & \multirow{3}{*}{$\begin{array}{l}\text { Helminth infection model } \\
\text { Mouse asthma models } \\
\text { IL-13 transgenic } \\
\text { IL-13 KO }\end{array}$} & Cloning of IL-13 receptors & $\begin{array}{l}\text { Gene association studies: } \\
\text { IL-13, IL-4, IL-4R } \alpha\end{array}$ \\
\hline & & $\begin{array}{l}\text { Preclinical IL-13 inhibitors: } \\
\text { Mutant-antagonist, IL13R } \alpha 2\end{array}$ & \\
\hline & & $\begin{array}{c}\text { Neutralizing } \\
\text { reagents for clinical use } \\
\text { Biomarkers }\end{array}$ & $\begin{array}{l}\text { Biomarkers } \\
\text { First clinical trials with } \\
\text { IL-13/IL-4 inhibitors }\end{array}$ \\
\hline$\vec{\nexists}$ & & & Successful clinical trial \\
\hline
\end{tabular}

dioisotope (which is suited for medical imaging) to the target molecule it would be possible to make diagnostic tests for brain cancer and follow-up tests after treatment with a more accurate method. Third, by taking a quick assessment of the compound binding we could determine whether over-expression of IL-13 is present which marks a high-grade astrocytoma. That would make an easy yet relatively cheap diagnostic kit for brain tumour tissue. And finally, instead of attaching a cellular toxin we could attach a targeting molecule to a small molecule with anti-tumour properties or a conventional chemotherapeutic. This would help to decrease toxicity of tissue and having potentially more effective tumour penetration.

Nowadays, IL-13 therapeutic applications in asthma are more advanced than ever. Table I chronologically highlights some of the findings in this field which led to the first successful clinical trial with IL-13/IL-4 inhibitor in asthma [200].

In 2011, Corren et al. [201] conducted the first successful clinical trial by hypothesizing that anti-IL-13 therapy would benefit patients with asthma who had a pretreatment profile consistent with IL-13 activity. Although, IL-4 and IL-13 are favourable targets for therapeutic applications in asthma, but agents targeting either IL-4 or IL-13 alone have shown limited efficacy in human clinical studies [202]. Subsequently, dual neutralization of IL-4 and IL-13 has been hypothesized to be a more promising therapeutic approach for asthma and allergy [203, 204]. 
In 2013, Redpath et al. [205] developed human neutralizing monoclonal antibodies against human IL-13R $\alpha 1$ subunit in vitro by utilizing the dual neutralization approach. They produced an antibody to the third ectodomain (D3) of IL-13R $\alpha 1$ which forms an essential binding site for both IL-13 and IL-4. This therapeutic approach could effectively neutralize the actions of both cytokines. This method comprises promising results and it may play a significant role in the prevention and treatment of asthma in the future.

The conduction of several successful Phase II clinical trials on human antiinterleukin-13/4 monoclonal antibodies such as Anrukinzumab, CNTO 5825, Tralokinumab, QAX576, Lebrikizumab and Dupilumab promises their therapeutic application in the near future. For some detailed reviews on the IL-13 role in the evolution of asthma therapy see the paper by Grunig et al. [200] and more recent papers by Dunn and Wechsler [206], Legrand and Klion [207] and Fahy [208].

\section{Summary and prospective}

IL-13 is one of the cytokines which plays an important mediator role in allergic inflammation. It is also known for contributing directly and indirectly to different inflammatory diseases. The biological properties of IL-13 and its signalling pathways have been characterized and pivotal roles of IL-13 in different pathogenic states have been established. It has been well demonstrated that IL-13 directs many of the important features of airway inflammation by accumulating strong experimental evidences over the years.

This particular cytokine shows important immunomodulatory activities on many cell types. However, its activities seem to be more restricted than those of IL-4. This behaviour is thought to be related to the distribution of IL-13R. As an example, IL-13 does not act on T cells and it is ineffective in directing Th2-cell differentiation in contrast to IL-4.

The cytokines produced by allergen-specific Th 2 cell induce and maintain allergic inflammatory processes and consequently the induction of differentiation of these cells represents the hallmark of allergic diseases.

IL-13 and its signalling pathways are briefly discussed in this review paper but, as mentioned, the precise molecular mechanisms have remained undetermined and require further investigations. Determination of the molecular mechanisms of IL-13 action will allow the development of compounds to target IL-13 for animal and human therapeutic applications. Finally we should emphasize that the intense ongoing investigation in this field will likely yield exciting new targets for related therapeutic applications. 


\section{Acknowledgements}

While this perspective reviewed only a limited number of publications on the role of IL-13 in human disease, we acknowledge the work that we could not cite here. The authors wish to acknowledge the anonymous reviewers for providing detailed and helpful comments to the manuscript.

\section{Conflict of Interests}

The authors declare that there is no conflict of interests regarding the publication of this article.

\section{References}

1. Rengarajan, J., Szabo, S. J., Glimcher, L. H.: Transcriptional regulation of Th1/Th2 polarization. Immunol Today 21, 479-483 (2000).

2. Brown, K. D., Zurawski, S. M., Mosmann, T. R., Zurawski, G.: A family of small inducible proteins secreted by leukocytes are members of a new superfamily that includes leukocyte and fibroblast-derived inflammatory agents, growth factors, and indicators of various activation processes. J Immunol 142, 679-687 (1989).

3. Cherwinski, H. M., Schumacher, J. H., Brown, K. D., Mosmann, T.: Two types of mouse helper T cell clone. III. Further differences in lymphokine synthesis between Th1 and Th2 clones revealed by RNA hybridization, functionally monospecific bioassays, and monoclonal antibodies. J Exp Med 166, 1229-1244 (1987).

4. Mosmann, T. R., Cherwinski, H., Bond, M., Giedlin, M., Coffman, R.: Two types of murine helper T cell clone. I. Definition according to profiles of lymphokine activities and secreted proteins. J Immunol 136, 2348-2357 (1986).

5. Minty, A., Chalon, P., Derocq, J. M., Dumont, X., Guillemot, J. C., Kaghad, M., Labit, C., Leplatois, P., Liauzun, P., Miloux, B., et al.: Interleukin-13 is a new human lymphokine regulating inflammatory and immune responses. Nature 362, 248-250 (1993).

6. Morgan, J. G., Dolganov, G. M., Robbins, S. E., Hinton, L. M., Lovett, M.: The selective isolation of novel cDNAs encoded by the regions surrounding the human interleukin 4 and 5 genes. Nucleic Acids Res 20, 5173-5179 (1992).

7. McKenzie, A. N., Culpepper, J. A., de Waal Malefyt, R., Briere, F., Punnonen, J., Aversa, G., Sato, A., Dang, W., Cocks, B. G., Menon, S., et al.: Interleukin 13, a T-cell-derived cytokine that regulates human monocyte and B-cell function. Proc Natl Acad Sci U S A 90, 3735-3739 (1993).

8. de Vries, J. E.: Molecular and biological characteristics of interleukin-13. Chem Immunol 63, 204-218 (1996).

9. Leonard, W. J., Lin, J. X.: Cytokine receptor signaling pathways. J Allergy Clin Immunol 105, 877-888 (2000).

10. Eisenmesser, E. Z., Horita, D. A., Altieri, A. S., Byrd, R. A.: Solution structure of interleukin-13 and insights into receptor engagement. J Mol Biol 310, 231-241 (2001). 
11. Kent, W. J., Sugnet, C. W., Furey, T. S., Roskin, K. M., Pringle, T. H., Zahler, A. M., Haussler, D.: The human genome browser at UCSC. Genome Research 12, 996-1006 (2002).

12. Smirnov, D. V., Smirnova, M. G., Korobko, V. G., Frolova, E. I.: Tandem arrangement of human genes for interleukin-4 and interleukin-13: Resemblance in their organization. Gene 155, 277-281 (1995).

13. Marsh, D. G., Neely, J. D., Breazeale, D. R., Ghosh, B., Freidhoff, L. R., Ehrlich-Kautzky, E., Schou, C., Krishnaswamy, G., Beaty, T. H.: Linkage analysis of IL4 and other chromosome $5 \mathrm{q} 31.1$ markers and total serum immunoglobulin $\mathrm{E}$ concentrations. Science 264, 1152-1156 (1994).

14. Meyers, D. A., Postma, D. S., Panhuysen, C. I., Xu, J., Amelung, P. J., Levitt, R. C., Bleecker, E. R.: Evidence for a locus regulating total serum IgE levels mapping to chromosome 5. Genomics 23, 464-470 (1994).

15. Postma, D. S., Bleecker, E. R., Amelung, P. J., Holroyd, K. J., Xu, J., Panhuysen, C. I., Meyers, D. A., Levitt, R. C.: Genetic susceptibility to asthma--Bronchial hyperresponsiveness coinherited with a major gene for atopy. N Engl J Med 333, 894-900 (1995).

16. Daniels, S. E., Bhattacharrya, S., James, A., Leaves, N. I., Young, A., Hill, M. R., Faux, J. A., Ryan, G. F., le Souef, P. N., Lathrop, G. M., Musk, A. W., Cookson, W. O.: A genomewide search for quantitative trait loci underlying asthma. Nature 383, 247-250 (1996).

17. Park, L. S., Friend, D., Sassenfeld, H. M., Urdal, D. L.: Characterization of the human B cell stimulatory factor 1 receptor. J Exp Med 166, 476-488 (1987).

18. Chomarat, P., Banchereau, J.: Interleukin-4 and interleukin-13: Their similarities and discrepancies. Int Rev Immunol 17, 1-52 (1998).

19. Tsarbopoulos, A., Varnerin, J., Cannon-Carlson, S., Wylie, D., Pramanik, B., Tang, J., Nagabhushan, T. L.: Mass spectrometric mapping of disulfide bonds in recombinant human interleukin-13. J Mass Spectrom 35, 446-453 (2000).

20. Vock, C., Yildirim, A. Ö., Wagner, C., Schlick, S., Lunding, L. P., Lee, C. G., Elias, J. A., Fehrenbach, H., Wegmann, M.: Distal airways are protected from goblet cell metaplasia by diminished expression of IL-13 signaling components. Clin Exp Allergy 45, 14471458 (2015).

21. Wills-Karp, M., Luyimbazi, J., Xu, X., Schofield, B., Neben, T. Y., Karp, C. L., Donaldson, D. D.: Interleukin-13: Central mediator of allergic asthma. Science 282, 2258-2261 (1998).

22. Grunig, G., Warnock, M., Wakil, A. E., Venkayya, R., Brombacher, F., Rennick, D. M., Sheppard, D., Mohrs, M., Donaldson, D. D., Locksley, R. M., Corry, D. B.: Requirement for IL-13 independently of IL-4 in experimental asthma. Science 282, 2261-2263 (1998).

23. Yi, T., Mui, A. L., Krystal, G., Ihle, J. N.: Hematopoietic cell phosphatase associates with the interleukin-3 (IL-3) receptor beta chain and down-regulates IL-3-induced tyrosine phosphorylation and mitogenesis. Mol Cell Biol 13, 7577-7586 (1993).

24. Chen, H. E., Chang, S., Trub, T., Neel, B. G.: Regulation of colony-stimulating factor 1 receptor signaling by the SH2 domain-containing tyrosine phosphatase SHPTP1. Mol Cell Biol 16, 3685-3697 (1996).

25. Klingmuller, U., Lorenz, U., Cantley, L. C., Neel, B. G., Lodish, H. F.: Specific recruitment of SH-PTP1 to the erythropoietin receptor causes inactivation of JAK2 and termination of proliferative signals. Cell 80, 729-738 (1995). 
26. Paulson, R. F., Vesely, S., Siminovitch, K. A., Bernstein, A.: Signalling by the W/Kit receptor tyrosine kinase is negatively regulated in vivo by the protein tyrosine phosphatase Shp1. Nat Genet 13, 309-315 (1996).

27. Gelderloos, J. A., Anderson, S. M.: Over-expression of protein tyrosine phosphatase 1 (PTP1) alters IL-3-dependent growth and tyrosine phosphorylation. Oncogene 13, 23672378 (1996).

28. Imani, F., Rager, K. J., Catipovic, B., Marsh, D. G.: Interleukin-4 (IL-4) induces phosphatidylinositol 3-kinase (p85) dephosphorylation. Implications for the role of SHP-1 in the IL-4-induced signals in human B cells. J Biol Chem 272, 7927-7931 (1997).

29. Nagarkar, D., Ramirez-Carrozzi, V., Choy, D., Lee, K., Soriano, R., Abbas, A., Modrusan, Z., Pappu, R., Arron, J.: Human mast cells and type 2 innate lymphoid cells activate gene expression and mucus composition in human bronchial epithelial cells via IL-13. Eur Respir J 44, P3898 (2014).

30. Wadsworth, S., Singhera, G., Dorscheid, D., Yang, S.: The regulation of interleukin-13 receptors in airway epithelial repair. Am J Respir Crit Care Med 189, A1066 (2014).

31. Mitchel, J., Antoniak, S., Kim, S.-H., McGill, M., Randell, S., Shore, S., Mackman, N., Park, J.-A.: IL-13 augments compression-induced exosomal tissue factor release from bronchial epithelial cells. The FASEB Journal 29, 863.21 (2015).

32. Haque, S. J., Harbor, P., Tabrizi, M., Yi, T., Williams, B. R.: Protein-tyrosine phosphatase Shp-1 is a negative regulator of IL-4- and IL-13-dependent signal transduction. J Biol Chem 273, 33893-33896 (1998).

33. Hershey, G. K., Friedrich, M. F., Esswein, L. A., Thomas, M. L., Chatila, T. A.: The association of atopy with a gain-of-function mutation in the alpha subunit of the interleukin-4 receptor. N Engl J Med 337, 1720-1725 (1997).

34. Haque, S. J., Wu, Q., Kammer, W., Friedrich, K., Smith, J. M., Kerr, I. M., Stark, G. R., Williams, B. R.: Receptor-associated constitutive protein tyrosine phosphatase activity controls the kinase function of JAK1. Proc Natl Acad Sci U S A 94, 8563-8568 (1997).

35. Reichel, M., Nelson, B. H., Greenberg, P. D., Rothman, P. B.: The IL-4 receptor alphachain cytoplasmic domain is sufficient for activation of JAK-1 and STAT6 and the induction of IL-4-specific gene expression. J Immunol 158, 5860-5867 (1997).

36. Yoshimura, A., Ohkubo, T., Kiguchi, T., Jenkins, N. A., Gilbert, D. J., Copeland, N. G., Hara, T., Miyajima, A.: A novel cytokine-inducible gene CIS encodes an SH2-containing protein that binds to tyrosine-phosphorylated interleukin 3 and erythropoietin receptors. EMBO J 14, 2816-2826 (1995).

37. Starr, R., Willson, T. A., Viney, E. M., Murray, L. J., Rayner, J. R., Jenkins, B. J., Gonda, T. J., Alexander, W. S., Metcalf, D., Nicola, N. A., Hilton, D. J.: A family of cytokineinducible inhibitors of signalling. Nature 387, 917-921 (1997).

38. Endo, T. A., Masuhara, M., Yokouchi, M., Suzuki, R., Sakamoto, H., Mitsui, K., Matsumoto, A., Tanimura, S., Ohtsubo, M., Misawa, H., Miyazaki, T., Leonor, N., Taniguchi, T., Fujita, T., Kanakura, Y., Komiya, S., Yoshimura, A.: A new protein containing an SH2 domain that inhibits JAK kinases. Nature 387, 921-924 (1997).

39. Galizzi, J. P., Zuber, C. E., Harada, N., Gorman, D. M., Djossou, O., Kastelein, R., Banchereau, J., Howard, M., Miyajima, A.: Molecular cloning of a cDNA encoding the human interleukin 4 receptor. Int Immunol 2, 669-675 (1990). 
40. Idzerda, R. L., March, C. J., Mosley, B., Lyman, S. D., Vanden Bos, T., Gimpel, S. D., Din, W. S., Grabstein, K. H., Widmer, M. B., Park, L. S., et al.: Human interleukin 4 receptor confers biological responsiveness and defines a novel receptor superfamily. J Exp Med 171, 861-873 (1990).

41. Aversa, G., Punnonen, J., Cocks, B. G., de Waal Malefyt, R., Vega, F., Jr., Zurawski, S. M., Zurawski, G., de Vries, J. E.: An interleukin 4 (IL-4) mutant protein inhibits both IL-4 or IL-13-induced human immunoglobulin G4 (IgG4) and IgE synthesis and B cell proliferation: Support for a common component shared by IL-4 and IL-13 receptors. J Exp Med 178, 2213-2218 (1993).

42. Kruse, N., Tony, H. P., Sebald, W.: Conversion of human interleukin-4 into a high affinity antagonist by a single amino acid replacement. EMBO J 11, 3237-3244 (1992).

43. Lefort, S., Vita, N., Reeb, R., Caput, D., Ferrara, P.: IL-13 and IL-4 share signal transduction elements as well as receptor components in TF-1 cells. FEBS Lett 366, 122-126 (1995).

44. Zurawski, S. M., Chomarat, P., Djossou, O., Bidaud, C., McKenzie, A. N., Miossec, P., Banchereau, J., Zurawski, G.: The primary binding subunit of the human interleukin-4 receptor is also a component of the interleukin-13 receptor. J Biol Chem 270, 1386913878 (1995).

45. Noguchi, M., Yi, H., Rosenblatt, H. M., Filipovich, A. H., Adelstein, S., Modi, W. S., McBride, O. W., Leonard, W. J.: Interleukin-2 receptor gamma chain mutation results in X-linked severe combined immunodeficiency in humans. Cell 73, 147-157 (1993).

46. Matthews, D. J., Clark, P. A., Herbert, J., Morgan, G., Armitage, R. J., Kinnon, C., Minty, A., Grabstein, K. H., Caput, D., Ferrara, P., et al.: Function of the interleukin-2 (IL-2) receptor gamma-chain in biologic responses of X-linked severe combined immunodeficient B cells to IL-2, IL-4, IL-13, and IL-15. Blood 85, 38-42 (1995).

47. Obiri, N. I., Murata, T., Debinski, W., Puri, R. K.: Modulation of interleukin (IL)-13 binding and signaling by the gammac chain of the IL-2 receptor. J Biol Chem 272, 20251-20258 (1997).

48. Aman, M. J., Tayebi, N., Obiri, N. I., Puri, R. K., Modi, W. S., Leonard, W. J.: cDNA cloning and characterization of the human interleukin 13 receptor alpha chain. J Biol Chem 271, 29265-29270 (1996).

49. Caput, D., Laurent, P., Kaghad, M., Lelias, J. M., Lefort, S., Vita, N., Ferrara, P.: Cloning and characterization of a specific interleukin (IL)-13 binding protein structurally related to the IL-5 receptor alpha chain. J Biol Chem 271, 16921-16926 (1996).

50. Hilton, D. J., Zhang, J. G., Metcalf, D., Alexander, W. S., Nicola, N. A., Willson, T. A.: Cloning and characterization of a binding subunit of the interleukin 13 receptor that is also a component of the interleukin 4 receptor. Proc Natl Acad Sci U S A 93, 497-501 (1996).

51. Miloux, B., Laurent, P., Bonnin, O., Lupker, J., Caput, D., Vita, N., Ferrara, P.: Cloning of the human IL-13R alphal chain and reconstitution with the IL4R alpha of a functional IL-4/IL-13 receptor complex. FEBS Lett 401, 163-166 (1997).

52. He, Y. W., Malek, T. R.: The IL-2 receptor gamma c chain does not function as a subunit shared by the IL-4 and IL-13 receptors. Implication for the structure of the IL-4 receptor. J Immunol 155, 9-12 (1995).

53. Andrews, R., Rosa, L., Daines, M., Khurana Hershey, G.: Reconstitution of a functional human type II IL-4/IL-13 receptor in mouse B cells: Demonstration of species specificity. J Immunol 166, 1716-1722 (2001). 
54. Gemou-Engesaeth, V.: Serum interleukin 13 (IL-13) and surfactant protein D (SP-D) expression is differentially associated with disease status in pediatric asthma patients. J Allergy Clin Immunol 133, AB148 (2014).

55. Donaldson, D. D., Whitters, M. J., Fitz, L. J., Neben, T. Y., Finnerty, H., Henderson, S. L., O’Hara, R. M., Jr., Beier, D. R., Turner, K. J., Wood, C. R., Collins, M.: The murine IL-13 receptor alpha 2: Molecular cloning, characterization, and comparison with murine IL-13 receptor alpha 1. J Immunol 161, 2317-2324 (1998).

56. Guo, J., Apiou, F., Mellerin, M. P., Lebeau, B., Jacques, Y., Minvielle, S.: Chromosome mapping and expression of the human interleukin-13 receptor. Genomics 42, 141-145 (1997).

57. Daines, M. O., Hershey, G. K.: A novel mechanism by which interferon-gamma can regulate interleukin (IL)-13 responses. Evidence for intracellular stores of IL-13 receptor alpha-2 and their rapid mobilization by interferon-gamma. J Biol Chem 277, 1038710393 (2002).

58. Mandal, D., Levine, A. D.: Elevated IL-13R $\alpha 2$ in intestinal epithelial cells from ulcerative colitis or colorectal cancer initiates MAPK pathway. Inflamm Bowel Dis 16, 753764 (2010).

59. Chen, W., Sivaprasad, U., Gibson, A. M., Ericksen, M. B., Cunningham, C. M., Bass, S. A., Kinker, K. G., Finkelman, F. D., Wills-Karp, M., Khurana Hershey, G. K.: IL-13 receptor $\alpha 2$ contributes to development of experimental allergic asthma. J Allergy Clin Immunol 132, 951-958. e956 (2013).

60. Konstantinidis, A., Puddicombe, S., Mochizuki, A., Sheth, P., Yang, I. A., Yoshisue, H., Wilson, S., Davies, D., Holgate, S., Holloway, J.: Cellular localization of interleukin 13 receptor alpha 2 in human primary bronchial epithelial cells and fibroblasts. J Investig Allergol Clin Immunol 18, 174 (2008).

61. Hershey, G. K.: IL-13 receptors and signaling pathways: an evolving web. J Allergy Clin Immunol 111, 677-690; quiz 691 (2003).

62. Huckabee, M., Newcomb, D., Boswell, M., Goleniewska, K., Reiss, S., Peebles, R.: TGF- $\beta$, IL- $1 \beta$, and IL-23 are required for IL-13R $\alpha 1$ expression on human Th17 cells and IL-13 attenuates IL-17A production at restimulation. J Allergy Clin Immunol 127, AB68 (2011).

63. Dhakal, M., Hardaway, J. C., Guloglu, F. B., Miller, M. M., Hoeman, C. M., Zaghouani, A. A., Wan, X., Rowland, L. M., Cascio, J. A., Sherman, M. P.: IL-13R $\alpha 1$ is a surface marker for M2 macrophages influencing their differentiation and function. Eur $\mathrm{J}$ Immunol 44, 842-855 (2014).

64. Takeda, K., Kamanaka, M., Tanaka, T., Kishimoto, T., Akira, S.: Impaired IL-13-mediated functions of macrophages in STAT6-deficient mice. J Immunol 157, 3220-3222 (1996).

65. Kaplan, M. H., Schindler, U., Smiley, S. T., Grusby, M. J.: Stat6 is required for mediating responses to IL-4 and for development of Th2 cells. Immunity 4, 313-319 (1996).

66. Welham, M. J., Learmonth, L., Bone, H., Schrader, J. W.: Interleukin-13 signal transduction in lymphohemopoietic cells. Similarities and differences in signal transduction with interleukin-4 and insulin. J Biol Chem 270, 12286-12296 (1995).

67. Wills-Karp, M.: IL-12/IL-13 axis in allergic asthma. J Allergy Clin Immunol 107, 9-18 (2001). 
68. Keegan, A. D., Nelms, K., White, M., Wang, L. M., Pierce, J. H., Paul, W. E.: An IL-4 receptor region containing an insulin receptor motif is important for IL-4-mediated IRS1 phosphorylation and cell growth. Cell 76, 811-820 (1994).

69. Kashiwada, M., Giallourakis, C. C., Pan, P. Y., Rothman, P. B.: Immunoreceptor tyrosine-based inhibitory motif of the IL-4 receptor associates with SH2-containing phosphatases and regulates IL-4-induced proliferation. J Immunol 167, 6382-6387 (2001).

70. Ryan, J. J., McReynolds, L. J., Keegan, A., Wang, L. H., Garfein, E., Rothman, P., Nelms, K., Paul, W. E.: Growth and gene expression are predominantly controlled by distinct regions of the human IL-4 receptor. Immunity 4, 123-132 (1996).

71. Callard, R. E., Matthews, D. J., Hibbert, L. M.: Interleukin 4 and interleukin 13: same response, different receptors. Biochem Soc Trans 25, 451-455 (1997).

72. Boulay, J.-L., Paul, W. E.: The interleukin-4 family of lymphokines. Curr Opin Immunol 4, 294-298 (1992).

73. McKenzie, A., Li, X., Largaespada, D., Sato, A., Kaneda, A., Zurawski, S., Doyle, E., Milatovich, A., Francke, U., Copeland, N.: Structural comparison and chromosomal localization of the human and mouse IL-13 genes. J Immunol 150, 5436-5444 (1993).

74. Heinzmann, A., Mao, X.-Q., Akaiwa, M., Kreomer, R., Gao, P.-S., Ohshima, K., Umeshita, R., Abe, Y., Braun, S., Yamashita, T.: Genetic variants of IL-13 signalling and human asthma and atopy. Hum Mol Genet 9, 549-559 (2000).

75. Chen, W., Sivaprasad, U., Tabata, Y., Gibson, A. M., Stier, M. T., Finkelman, F. D., Hershey, G. K. K.: IL-13R $\alpha 2$ membrane and soluble isoforms differ in humans and mice. J Immunol 183, 7870-7876 (2009).

76. Akinbami, O. J., Moorman, J. E., Liu, X.: Asthma prevalence, health care use, and mortality: United States, 2005-2009. Natl Health Stat Report 32, 1-14 (2011).

77. Wills-Karp, M.: Interleukin-13 in asthma pathogenesis. Immunol Rev 202, 175-190 (2004).

78. Murphy, D. M.: Recent advances in the pathophysiology of asthma. CHEST Journal 137, 1417-1426 (2010).

79. Wills-Karp, M.: Immunologic basis of antigen-induced airway hyperresponsiveness. Annu Rev Immunol 17, 255-281 (1999).

80. Vercelli, D., Gozdz, J., von Mutius, E.: Innate lymphoid cells in asthma: When innate immunity comes in a Th2 flavor. Curr Opin Allergy Clin Immunol 14, 29-34 (2014).

81. Sterk, P. J., Lutter, R.: Asthma phenotyping: TH2-high, TH2-low, and beyond. J Allergy Clin Immunol 133, 395-396 (2014).

82. Lukacs, N. W., Tekkanat, K. K.: Role of chemokines in asthmatic airway inflammation. Immunol Rev 177, 21-30 (2000).

83. Brusselle, G., Kips, J., Joos, G., Bluethmann, H., Pauwels, R.: Allergen-induced airway inflammation and bronchial responsiveness in wild-type and interleukin-4-deficient mice. Am J Respir Cell Mol Biol 12, 254-259 (1995).

84. Kuperman, D., Schofield, B., Wills-Karp, M., Grusby, M. J.: Signal transducer and activator of transcription factor 6 (Stat6)-deficient mice are protected from antigen-induced airway hyperresponsiveness and mucus production. J Exp Med 187, 939-948 (1998).

85. Gavett, S. H., O’Hearn, D. J., Karp, C. L., Patel, E. A., Schofield, B. H., Finkelman, F. D., Wills-Karp, M.: Interleukin-4 receptor blockade prevents airway responses induced by antigen challenge in mice. Am J Physiol 272, L253-261 (1997). 
86. Zhu, Z., Homer, R. J., Wang, Z., Chen, Q., Geba, G. P., Wang, J., Zhang, Y., Elias, J. A.: Pulmonary expression of interleukin-13 causes inflammation, mucus hypersecretion, subepithelial fibrosis, physiologic abnormalities, and eotaxin production. J Clin Invest 103, 779-788 (1999).

87. Webb, D. C., McKenzie, A. N., Koskinen, A. M., Yang, M., Mattes, J., Foster, P. S.: Integrated signals between IL-13, IL-4, and IL-5 regulate airways hyperreactivity. J Immunol 165, 108-113 (2000).

88. Walter, D. M., McIntire, J. J., Berry, G., McKenzie, A. N., Donaldson, D. D., DeKruyff, R. H., Umetsu, D. T.: Critical role for IL-13 in the development of allergen-induced airway hyperreactivity. J Immunol 167, 4668-4675 (2001).

89. Ingram, J. L., Kraft, M.: IL-13 in asthma and allergic disease: Asthma phenotypes and targeted therapies. J Allergy Clin Immunol 130, 829-842 (2012).

90. Elias, J. A., Lee, C. G.: IL-13 in asthma: the successful integration of lessons from mice and humans. Am J Respir Crit Care Med 183, 957-958 (2011).

91. Bottema, R. W., Nolte, I. M., Howard, T. D., Koppelman, G. H., Dubois, A. E., de Meer, G., Kerkhof, M., Bleecker, E. R., Meyers, D. A., Postma, D. S.: Interleukin 13 and interleukin 4 receptor- $\alpha$ polymorphisms in rhinitis and asthma. Int Arch Allergy Immunol 153, 259-267 (2010).

92. Hussain, S., Tahir, A.: IL-13 gene polymorphisms and their association with atopic asthma and rhinitis in Pakistani patients. Iran J Allergy Asthma Immunol 13, 298299 (2014).

93. Undarmaa, S., Mashimo, Y., Hattori, S., Shimojo, N., Fujita, K., Miyatake, A., Doi, S., Kohno, Y., Okamoto, Y., Hirota, T.: Replication of genetic association studies in asthma and related phenotypes. J Human Genet 55, 342-349 (2010).

94. Shazia, M., Kanza, M., Mehwish, I., Irum, S., Farida, A., Asifa, A.: IL-13 gene polymorphisms and their association with atopic asthma and rhinitis in Pakistani patients. Iran J Allergy Asthma Immunol 12, (2013).

95. Nie, W., Liu, Y., Bian, J., Li, B., Xiu, Q.: Effects of polymorphisms-1112C/T and+ 2044A/G in interleukin-13 gene on asthma risk: A meta-analysis. PLoS ONE 8, e56065 (2013).

96. Vercelli, D.: Discovering susceptibility genes for asthma and allergy. Nat Rev Immunol 8, 169-182 (2008).

97. Brightling, C., Saha, S., Hollins, F.: Interleukin-13: prospects for new treatments. Clin Exp Allergy 40, 42-49 (2010).

98. Hershey, G. K. K.: IL-13 receptors and signaling pathways: An evolving web. J Allergy Clin Immunol 111, 677-690 (2003).

99. Mathew, A., MacLean, J. A., DeHaan, E., Tager, A. M., Green, F. H., Luster, A. D.: Signal transducer and activator of transcription 6 controls chemokine production and $T$ helper cell type 2 cell trafficking in allergic pulmonary inflammation. J Exp Med 193, 1087-1096 (2001).

100. Francisco, D., Thomas, J., Lugogo, N., Que, L., Ledford, J., Choudhury, S., Beaver, D., Kraft, M., Wang, Y.: Surfactant protein A inhibits Il-13-induced pro-inflammatory response in asthmatic airway epithelial cells. Am J Respir Crit Care Med 187, A3555 (2013).

101. Gabrielli, A., Avvedimento, E. V., Krieg, T.: Scleroderma. N Engl J Med 360, 1989-2003 (2009). 
102. Gu, Y. S., Kong, J., Cheema, G. S., Keen, C. L., Wick, G., Gershwin, M. E.: The immunobiology of systemic sclerosis. Semin Arthritis Rheum 38, 132-160 (2008).

103. Varga, J., Abraham, D.: Systemic sclerosis: A prototypic multisystem fibrotic disorder. J Clin Invest 117, 557-567 (2007).

104. Mayes, M. D.: Scleroderma epidemiology. Rheum Dis Clin North Am 29, 239-254 (2003).

105. Kissin, E. Y., Korn, J. H.: Fibrosis in scleroderma. Rheum Dis Clin North Am 29, 351369 (2003).

106. Baraut, J., Farge, D., Jean-Louis, F., Kesmandt, H., Durant, C., Verrecchia, F., Michel, L.: [Cytokines in systemic sclerosis]. Pathol Biol (Paris) 60, 127-139 (2012).

107. Wynn, T. A.: Fibrotic disease and the $\mathrm{T}(\mathrm{H}) 1 / \mathrm{T}(\mathrm{H}) 2$ paradigm. Nat Rev Immunol 4, $583-$ 594 (2004).

108. Lee, C. G., Homer, R. J., Zhu, Z., Lanone, S., Wang, X., Koteliansky, V., Shipley, J. M., Gotwals, P., Noble, P., Chen, Q., Senior, R. M., Elias, J. A.: Interleukin-13 induces tissue fibrosis by selectively stimulating and activating transforming growth factor beta(1). J Exp Med 194, 809-821 (2001).

109. Lanone, S., Zheng, T., Zhu, Z., Liu, W., Lee, C. G., Ma, B., Chen, Q., Homer, R. J., Wang, J., Rabach, L. A., Rabach, M. E., Shipley, J. M., Shapiro, S. D., Senior, R. M., Elias, J. A.: Overlapping and enzyme-specific contributions of matrix metalloproteinases-9 and -12 in IL-13-induced inflammation and remodeling. J Clin Invest 110, 463-474 (2002).

110. Granel, B., Allanore, Y., Chevillard, C., Arnaud, V., Marquet, S., Weiller, P. J., Durand, J. M., Harle, J. R., Grange, C., Frances, Y., Berbis, P., Gaudart, J., de Micco, P., Kahan, A., Dessein, A.: IL13RA2 gene polymorphisms are associated with systemic sclerosis. J Rheumatol 33, 2015-2019 (2006).

111. Fuschiotti, P.: Role of IL-13 in systemic sclerosis. Cytokine 56, 544-549 (2011).

112. Aliprantis, A. O., Wang, J., Fathman, J. W., Lemaire, R., Dorfman, D. M., Lafyatis, R., Glimcher, L. H.: Transcription factor T-bet regulates skin sclerosis through its function in innate immunity and via IL-13. Proc Natl Acad Sci U S A 104, 2827-2830 (2007).

113. Rankin, A. L., Mumm, J. B., Murphy, E., Turner, S., Yu, N., McClanahan, T. K., Bourne, P. A., Pierce, R. H., Kastelein, R., Pflanz, S.: IL-33 induces IL-13-dependent cutaneous fibrosis. J Immunol 184, 1526-1535 (2010).

114. Hasegawa, M., Fujimoto, M., Kikuchi, K., Takehara, K.: Elevated serum levels of interleukin 4 (IL-4), IL-10, and IL-13 in patients with systemic sclerosis. J Rheumatol 24, 328-332 (1997).

115. Riccieri, V., Rinaldi, T., Spadaro, A., Scrivo, R., Ceccarelli, F., Franco, M. D., Taccari, E., Valesini, G.: Interleukin-13 in systemic sclerosis: relationship to nailfold capillaroscopy abnormalities. Clin Rheumatol 22, 102-106 (2003).

116. Fuschiotti, P., Medsger, T. A., Jr., Morel, P. A.: Effector CD8+ T cells in systemic sclerosis patients produce abnormally high levels of interleukin-13 associated with increased skin fibrosis. Arthritis Rheum 60, 1119-1128 (2009).

117. Fuschiotti, P.: CD8+ T cells in systemic sclerosis. Immunol Res 50, 188-194 (2011).

118. Falkner, D., Wilson, J., Fertig, N., Clawson, K., Medsger, T. A., Jr., Morel, P. A.: Studies of HLA-DR and DQ alleles in systemic sclerosis patients with autoantibodies to RNA polymerases and U3-RNP (fibrillarin). J Rheumatol 27, 1196-1202 (2000).

119. Johnson, R. W., Tew, M. B., Arnett, F. C.: The genetics of systemic sclerosis. Curr Rheumatol Rep 4, 99-107 (2002). 
120. Zheng, W., Flavell, R. A.: The transcription factor GATA-3 is necessary and sufficient for Th2 cytokine gene expression in CD4 T cells. Cell 89, 587-596 (1997).

121. Ouyang, W., Lohning, M., Gao, Z., Assenmacher, M., Ranganath, S., Radbruch, A., Murphy, K. M.: Stat6-independent GATA-3 autoactivation directs IL-4-independent Th2 development and commitment. Immunity 12, 27-37 (2000).

122. Ho, I. C., Glimcher, L. H.: Transcription: Tantalizing times for T cells. Cell 109 Suppl, S109-120 (2002).

123. Zhou, M., Ouyang, W.: The function role of GATA-3 in Th1 and Th2 differentiation. Immunol Res 28, 25-37 (2003).

124. Lavenu-Bombled, C., Trainor, C. D., Makeh, I., Romeo, P. H., Max-Audit, I.: Interleukin-13 gene expression is regulated by GATA-3 in T cells: Role of a critical association of a GATA and two GATG motifs. J Biol Chem 277, 18313-18321 (2002).

125. Kishikawa, H., Sun, J., Choi, A., Miaw, S. C., Ho, I. C.: The cell type-specific expression of the murine IL-13 gene is regulated by GATA-3. J Immunol 167, 4414-4420 (2001).

126. Medsger, T. A., Jr., Ivanco, D. E., Kardava, L., Morel, P. A., Lucas, M. R., Fuschiotti, P.: GATA-3 up-regulation in CD8+ T cells as a biomarker of immune dysfunction in systemic sclerosis, resulting in excessive interleukin-13 production. Arthritis Rheum 63, 1738-1747 (2011).

127. Tan, F. K., Zhou, X., Mayes, M. D., Gourh, P., Guo, X., Marcum, C., Jin, L., Arnett, F. C., Jr.: Signatures of differentially regulated interferon gene expression and vasculotrophism in the peripheral blood cells of systemic sclerosis patients. Rheumatology (Oxford) 45, 694-702 (2006).

128. Paul, W. E., Zhu, J.: How are $\mathrm{T}(\mathrm{H}) 2$-type immune responses initiated and amplified? Nat Rev Immunol 10, 225-235 (2010).

129. Szabo, S. J., Kim, S. T., Costa, G. L., Zhang, X., Fathman, C. G., Glimcher, L. H.: A novel transcription factor, T-bet, directs Th1 lineage commitment. Cell 100, 655-669 (2000).

130. Szabo, S. J., Sullivan, B. M., Stemmann, C., Satoskar, A. R., Sleckman, B. P., Glimcher, L. H.: Distinct effects of T-bet in TH1 lineage commitment and IFN-gamma production in CD4 and CD8 T cells. Science 295, 338-342 (2002).

131. Mullen, A. C., High, F. A., Hutchins, A. S., Lee, H. W., Villarino, A. V., Livingston, D. M., Kung, A. L., Cereb, N., Yao, T. P., Yang, S. Y., Reiner, S. L.: Role of T-bet in commitment of TH1 cells before IL-12-dependent selection. Science 292, 1907-1910 (2001).

132. Usui, T., Preiss, J. C., Kanno, Y., Yao, Z. J., Bream, J. H., O’Shea, J. J., Strober, W.: T-bet regulates Th1 responses through essential effects on GATA-3 function rather than on IFNG gene acetylation and transcription. J Exp Med 203, 755-766 (2006).

133. Suzuki, K., Kaminuma, O., Hiroi, T., Kitamura, F., Miyatake, S., Takaiwa, F., Tatsumi, H., Nemoto, S., Kitamura, N., Mori, A.: Downregulation of IL-13 gene transcription by T-bet in human T cells. Int Arch Allergy Immunol 146 Suppl 1, 33-35 (2008).

134. Ho, I. C., Pai, S. Y.: GATA-3 - not just for Th2 cells anymore. Cell Mol Immunol 4, 15-29 (2007).

135. Gourh, P., Agarwal, S. K., Divecha, D., Assassi, S., Paz, G., Arora-Singh, R. K., Reveille, J. D., Shete, S., Mayes, M. D., Arnett, F. C., Tan, F. K.: Polymorphisms in TBX21 and STAT4 increase the risk of systemic sclerosis: Evidence of possible gene-gene interaction and alterations in Th1/Th2 cytokines. Arthritis Rheum 60, 3794-3806 (2009). 
136. Mannon, P., Reinisch, W.: Interleukin 13 and its role in gut defence and inflammation. Gut 61, 1765-1773 (2012).

137. Wu, D., Ahrens, R., Osterfeld, H., Noah, T. K., Groschwitz, K., Foster, P. S., Steinbrecher, K. A., Rothenberg, M. E., Shroyer, N. F., Matthaei, K. I., Finkelman, F. D., Hogan, S. P.: Interleukin-13 (IL-13)/IL-13 receptor alphal (IL-13Ralphal) signaling regulates intestinal epithelial cystic fibrosis transmembrane conductance regulator channel-dependent Cl-secretion. J Biol Chem 286, 13357-13369 (2011).

138. Hering, N. A., Fromm, M., Schulzke, J. D.: Determinants of colonic barrier function in inflammatory bowel disease and potential therapeutics. J Physiol 590, 1035-1044 (2012).

139. Bancroft, A. J., McKenzie, A. N., Grencis, R. K.: A critical role for IL-13 in resistance to intestinal nematode infection. J Immunol 160, 3453-3461 (1998).

140. Urban, J. F., Jr., Noben-Trauth, N., Donaldson, D. D., Madden, K. B., Morris, S. C., Collins, M., Finkelman, F. D.: IL-13, IL-4Ralpha, and Stat6 are required for the expulsion of the gastrointestinal nematode parasite Nippostrongylus brasiliensis. Immunity 8, 255-264 (1998).

141. Else, K. J., Grencis, R. K.: Antibody-independent effector mechanisms in resistance to the intestinal nematode parasite Trichuris muris. Infect Immun 64, 2950-2954 (1996).

142. Newcomb, D. C., Boswell, M. G., Huckabee, M. M., Goleniewska, K., Dulek, D. E., Reiss, S., Lukacs, N. W., Kolls, J. K., Peebles, R. S., Jr.: IL-13 regulates Th17 secretion of IL-17A in an IL-10-dependent manner. J Immunol 188, 1027-1035 (2012).

143. Newcomb, D. C., Zhou, W., Moore, M. L., Goleniewska, K., Hershey, G. K., Kolls, J. K., Peebles, R. S., Jr.: A functional IL-13 receptor is expressed on polarized murine CD4+ Th17 cells and IL-13 signaling attenuates Th17 cytokine production. J Immunol 182, 5317-5321 (2009).

144. Newcomb, D. C., Boswell, M. G., Zhou, W., Huckabee, M. M., Goleniewska, K., Sevin, C. M., Hershey, G. K., Kolls, J. K., Peebles, R. S., Jr.: Human TH17 cells express a functional IL-13 receptor and IL-13 attenuates IL-17A production. J Allergy Clin Immunol 127, 1006-1013, e1001-1004 (2011).

145. Boirivant, M., Fuss, I. J., Chu, A., Strober, W.: Oxazolone colitis: A murine model of T helper cell type 2 colitis treatable with antibodies to interleukin 4. J Exp Med 188, 1929 1939 (1998).

146. Heller, F., Fuss, I. J., Nieuwenhuis, E. E., Blumberg, R. S., Strober, W.: Oxazolone colitis, a Th2 colitis model resembling ulcerative colitis, is mediated by IL-13-producing NK-T cells. Immunity 17, 629-638 (2002).

147. Scanlon, S. T., Thomas, S. Y., Ferreira, C. M., Bai, L., Krausz, T., Savage, P. B., Bendelac, A.: Airborne lipid antigens mobilize resident intravascular NKT cells to induce allergic airway inflammation. J Exp Med 208, 2113-2124 (2011).

148. Fuss, I. J., Heller, F., Boirivant, M., Leon, F., Yoshida, M., Fichtner-Feigl, S., Yang, Z., Exley, M., Kitani, A., Blumberg, R. S., Mannon, P., Strober, W.: Nonclassical CD1d-restricted NK T cells that produce IL-13 characterize an atypical Th2 response in ulcerative colitis. J Clin Invest 113, 1490-1497 (2004).

149. Rosen, M. J., Frey, M. R., Washington, M. K., Chaturvedi, R., Kuhnhein, L. A., Matta, P., Revetta, F. L., Wilson, K. T., Polk, D. B.: STAT6 activation in ulcerative colitis: A new target for prevention of IL-13-induced colon epithelial cell dysfunction. Inflamm Bowel Dis 17, 2224-2234 (2011). 
150. Kawashima, R., Kawamura, Y. I., Oshio, T., Son, A., Yamazaki, M., Hagiwara, T., Okada, T., Inagaki-Ohara, K., Wu, P., Szak, S., Kawamura, Y. J., Konishi, F., Miyake, O., Yano, H., Saito, Y., Burkly, L. C., Dohi, T.: Interleukin-13 damages intestinal mucosa via TWEAK and Fn14 in mice-A pathway associated with ulcerative colitis. Gastroenterology 141, 2119-2129, e2118 (2011).

151. McDermott, J. R., Humphreys, N. E., Forman, S. P., Donaldson, D. D., Grencis, R. K.: Intraepithelial NK cell-derived IL-13 induces intestinal pathology associated with nematode infection. J Immunol 175, 3207-3213 (2005).

152. Gonsalves, N., Yang, G. Y., Doerfler, B., Ritz, S., Ditto, A. M., Hirano, I.: Elimination diet effectively treats eosinophilic esophagitis in adults; food reintroduction identifies causative factors. Gastroenterology 142, 1451-1459, e1451; quiz e1414-1455 (2012).

153. Mishra, A., Rothenberg, M. E.: Intratracheal IL-13 induces eosinophilic esophagitis by an IL-5, eotaxin-1, and STAT6-dependent mechanism. Gastroenterology 125, 1419-1427 (2003).

154. Akei, H. S., Mishra, A., Blanchard, C., Rothenberg, M. E.: Epicutaneous antigen exposure primes for experimental eosinophilic esophagitis in mice. Gastroenterology 129, 985-994 (2005).

155. Zuo, L., Fulkerson, P. C., Finkelman, F. D., Mingler, M., Fischetti, C. A., Blanchard, C., Rothenberg, M. E.: IL-13 induces esophageal remodeling and gene expression by an eosinophil-independent, IL-13R alpha 2-inhibited pathway. J Immunol 185, 660-669 (2010).

156. Neilsen, C. V., Bryce, P. J.: Interleukin-13 directly promotes oesophagus production of CCL11 and CCL24 and the migration of eosinophils. Clin Exp Allergy 40, 427-434 (2010).

157. Blanchard, C., Stucke, E. M., Rodriguez-Jimenez, B., Burwinkel, K., Collins, M. H., Ahrens, A., Alexander, E. S., Butz, B. K., Jameson, S. C., Kaul, A., Franciosi, J. P., Kushner, J. P., Putnam, P. E., Abonia, J. P., Rothenberg, M. E.: A striking local esophageal cytokine expression profile in eosinophilic esophagitis. J Allergy Clin Immunol 127, 208-217, e201-207 (2011).

158. Frischmeyer-Guerrerio, P. A., Guerrerio, A. L., Chichester, K. L., Bieneman, A. P., Hamilton, R. A., Wood, R. A., Schroeder, J. T.: Dendritic cell and T cell responses in children with food allergy. Clin Exp Allergy 41, 61-71 (2011).

159. Chiaramonte, M. G., Donaldson, D. D., Cheever, A. W., Wynn, T. A.: An IL-13 inhibitor blocks the development of hepatic fibrosis during a T-helper type 2-dominated inflammatory response. J Clin Invest 104, 777-785 (1999).

160. Matsushita, M., Yamamoto, T., Nishioka, K.: Upregulation of interleukin-13 and its receptor in a murine model of bleomycin-induced scleroderma. Int Arch Allergy Immunol 135, 348-356 (2004).

161. Wallace, W. A., Ramage, E. A., Lamb, D., Howie, S. E.: A type 2 (Th2-like) pattern of immune response predominates in the pulmonary interstitium of patients with cryptogenic fibrosing alveolitis (CFA). Clin Exp Immunol 101, 436-441 (1995).

162. Wilson, M. S., Wynn, T. A.: Pulmonary fibrosis: Pathogenesis, etiology and regulation. Mucosal Immunol 2, 103-121 (2009).

163. Scharl, M., Frei, S., Pesch, T., Kellermeier, S., Arikkat, J., Frei, P., Fried, M., Weber, A., Jehle, E., Ruhl, A., Rogler, G.: Interleukin-13 and transforming growth factor beta synergise in the pathogenesis of human intestinal fistulae. Gut 62, 63-72 (2013). 
164. Badalyan, V., Thompson, R. W., Wynn, T. A., Ramalingam, T. R.: Tu1723 TNFA and IL-17 synergize to inhibit IL-13 bioactivity via IL-13Ra2 induction in human colonic fibroblasts. Gastroenterology 146, S-826 (2014).

165. Kobayashi, M., Kobayashi, H., Pollard, R. B., Suzuki, F.: A pathogenic role of Th2 cells and their cytokine products on the pulmonary metastasis of murine B16 melanoma. J Immunol 160, 5869-5873 (1998).

166. Terabe, M., Park, J. M., Berzofsky, J. A.: Role of IL-13 in regulation of anti-tumor immunity and tumor growth. Cancer Immunol Immunother 53, 79-85 (2004).

167. Kacha, A. K., Fallarino, F., Markiewicz, M. A., Gajewski, T. F.: Cutting edge: Spontaneous rejection of poorly immunogenic P1.HTR tumors by Stat6-deficient mice. J Immunol 165, 6024-6028 (2000).

168. Ostrand-Rosenberg, S., Grusby, M. J., Clements, V. K.: Cutting edge: STAT6-deficient mice have enhanced tumor immunity to primary and metastatic mammary carcinoma. J Immunol 165, 6015-6019 (2000).

169. Terabe, M., Matsui, S., Noben-Trauth, N., Chen, H., Watson, C., Donaldson, D. D., Carbone, D. P., Paul, W. E., Berzofsky, J. A.: NKT cell-mediated repression of tumor immunosurveillance by IL-13 and the IL-4R-STAT6 pathway. Nat Immunol 1, 515-520 (2000).

170. Terabe, M., Matsui, S., Park, J. M., Mamura, M., Noben-Trauth, N., Donaldson, D. D., Chen, W., Wahl, S. M., Ledbetter, S., Pratt, B., Letterio, J. J., Paul, W. E., Berzofsky, J. A.: Transforming growth factor-beta production and myeloid cells are an effector mechanism through which CD1d-restricted $\mathrm{T}$ cells block cytotoxic $\mathrm{T}$ lymphocyte-mediated tumor immunosurveillance: Abrogation prevents tumor recurrence. J Exp Med 198, $1741-1752$ (2003).

171. Ostrand-Rosenberg, S., Clements, V. K., Terabe, M., Park, J. M., Berzofsky, J. A., Dissanayake, S. K.: Resistance to metastatic disease in STAT6-deficient mice requires hemopoietic and nonhemopoietic cells and is IFN-gamma dependent. J Immunol 169, 5796-5804 (2002).

172. Ahlers, J. D., Belyakov, I. M., Terabe, M., Koka, R., Donaldson, D. D., Thomas, E. K., Berzofsky, J. A.: A push-pull approach to maximize vaccine efficacy: Abrogating suppression with an IL-13 inhibitor while augmenting help with granulocyte/macrophage colony-stimulating factor and CD40L. Proc Natl Acad Sci U S A 99, 13020-13025 (2002).

173. Berzofsky, J. A., Ahlers, J. D., Belyakov, I. M.: Strategies for designing and optimizing new generation vaccines. Nat Rev Immunol 1, 209-219 (2001).

174. Kawakami, K., Kawakami, M., Snoy, P. J., Husain, S. R., Puri, R. K.: In vivo overexpression of IL-13 receptor alpha 2 chain inhibits tumorigenicity of human breast and pancreatic tumors in immunodeficient mice. J Exp Med 194, 1743-1754 (2001).

175. Lebel-Binay, S., Laguerre, B., Quintin-Colonna, F., Conjeaud, H., Magazin, M., Miloux, B., Pecceu, F., Caput, D., Ferrara, P., Fradelizi, D.: Experimental gene therapy of cancer using tumor cells engineered to secrete interleukin-13. Eur J Immunol 25, 2340-2348 (1995).

176. Chaouchi, N., Wallon, C., Goujard, C., Tertian, G., Rudent, A., Caput, D., Ferrera, P., Minty, A., Vazquez, A., Delfraissy, J. F.: Interleukin-13 inhibits interleukin-2-induced proliferation and protects chronic lymphocytic leukemia B cells from in vitro apoptosis. Blood 87, 1022-1029 (1996). 
177. Kawakami, K., Joshi, B. H., Puri, R. K.: Sensitization of cancer cells to interleukin 13-pseudomonas exotoxin-induced cell death by gene transfer of interleukin 13 receptor alpha chain. Hum Gene Ther 11, 1829-1835 (2000).

178. Joshi, B. H., Kawakami, K., Leland, P., Puri, R. K.: Heterogeneity in interleukin-13 receptor expression and subunit structure in squamous cell carcinoma of head and neck: Differential sensitivity to chimeric fusion proteins comprised of interleukin-13 and a mutated form of Pseudomonas exotoxin. Clin Cancer Res 8, 1948-1956 (2002).

179. Gabay, C., Porter, B., Guenette, D., Billir, B., Arend, W. P.: Interleukin-4 (IL-4) and IL13 enhance the effect of IL-1beta on production of IL-1 receptor antagonist by human primary hepatocytes and hepatoma HepG2 cells: Differential effect on C-reactive protein production. Blood 93, 1299-1307 (1999).

180. Kawakami, K., Husain, S. R., Bright, R. K., Puri, R. K.: Gene transfer of interleukin 13 receptor alpha2 chain dramatically enhances the antitumor effect of IL-13 receptor-targeted cytotoxin in human prostate cancer xenografts. Cancer Gene Ther 8, 861-868 (2001).

181. Kanai, T., Watanabe, M., Hayashi, A., Nakazawa, A., Yajima, T., Okazawa, A., Yamazaki, M., Ishii, H., Hibi, T.: Regulatory effect of interleukin-4 and interleukin-13 on colon cancer cell adhesion. Br J Cancer 82, 1717-1723 (2000).

182. Kapp, U., Yeh, W. C., Patterson, B., Elia, A. J., Kagi, D., Ho, A., Hessel, A., Tipsword, M., Williams, A., Mirtsos, C., Itie, A., Moyle, M., Mak, T. W.: Interleukin 13 is secreted by and stimulates the growth of Hodgkin and Reed-Sternberg cells. J Exp Med 189, 1939-1946 (1999).

183. Skinnider, B. F., Elia, A. J., Gascoyne, R. D., Patterson, B., Trumper, L., Kapp, U., Mak, T. W.: Signal transducer and activator of transcription 6 is frequently activated in Hodgkin and Reed-Sternberg cells of Hodgkin lymphoma. Blood 99, 618-626 (2002).

184. Skinnider, B. F., Elia, A. J., Gascoyne, R. D., Trumper, L. H., von Bonin, F., Kapp, U., Patterson, B., Snow, B. E., Mak, T. W.: Interleukin 13 and interleukin 13 receptor are frequently expressed by Hodgkin and Reed-Sternberg cells of Hodgkin lymphoma. Blood 97, 250-255 (2001).

185. Skinnider, B. F., Kapp, U., Mak, T. W.: The role of interleukin 13 in classical Hodgkin lymphoma. Leuk Lymphoma 43, 1203-1210 (2002).

186. Kawakami, M., Leland, P., Kawakami, K., Puri, R. K.: Mutation and functional analysis of IL-13 receptors in human malignant glioma cells. Oncol Res 12, 459-467 (2001).

187. Babaloo, Z., Kaye, P. M., Eslami, M. B.: Interleukin-13 in Iranian patients with visceral leishmaniasis: Relationship to other Th2 and Th1 cytokines. T Roy Soc Trop Med H 95, 85-88 (2001).

188. Chen, L., Shen, Y., Liu, L., Li, X., Wang, T., Wen, F.: Interleukin-13 - 1112 C/T promoter polymorphism confers risk for COPD: A meta-analysis. PLoS ONE 8, e68222 (2013).

189. Seyfizadeh, N., Kazemi, T., Farhoudi, M., Aliparasti, M. R., Sadeghi-Bazargani, H., Almasi, S., Babaloo, Z.: Association of IL-13 single nucleotide polymorphisms in Iranian patients to multiple sclerosis. Am J Clin Exp Immunol 3, 124 (2014).

190. Yang, G., Volk, A., Petley, T., Emmell, E., Giles-Komar, J., Shang, X., Li, J., Das, A. M., Shealy, D., Griswold, D. E., Li, L.: Anti-IL-13 monoclonal antibody inhibits airway hyperresponsiveness, inflammation and airway remodeling. Cytokine 28, 224-232 (2004). 
191. Oh, C., Geba, G., Molfino, N.: Investigational therapeutics targeting the IL-4/IL-13/ STAT-6 pathway for the treatment of asthma. Eur Respir Rev 19, 46-54 (2010).

192. Holgate, S. T.: Pathophysiology of asthma: What has our current understanding taught us about new therapeutic approaches? J Allergy Clin Immunol 128, 495-505 (2011).

193. Mitchell, J., Dimov, V., Townley, R. G.: IL-13 and the IL-13 receptor as therapeutic targets for asthma and allergic disease. Curr Opin Investig Drugs (London, England: 2000) 11, 527-534 (2010).

194. Kasaian, M. T., Donaldson, D. D., Tchistiakova, L., Marquette, K., Tan, X. Y., Ahmed, A., Jacobson, B. A., Widom, A., Cook, T. A., Xu, X., Barry, A. B., Goldman, S. J., Abraham, W. M.: Efficacy of IL-13 neutralization in a sheep model of experimental asthma. Am J Respir Cell Mol Biol 36, 368-376 (2007).

195. Bree, A., Schlerman, F. J., Wadanoli, M., Tchistiakova, L., Marquette, K., Tan, X. Y., Jacobson, B. A., Widom, A., Cook, T. A., Wood, N., Vunnum, S., Krykbaev, R., Xu, X., Donaldson, D. D., Goldman, S. J., Sypek, J., Kasaian, M. T.: IL-13 blockade reduces lung inflammation after Ascaris suum challenge in cynomolgus monkeys. J Allergy Clin Immunol 119, 1251-1257 (2007).

196. Ma, Y., Hayglass, K. T., Becker, A. B., Halayko, A. J., Basu, S., Simons, F. E., Peng, Z.: Novel cytokine peptide-based vaccines: An interleukin-4 vaccine suppresses airway allergic responses in mice. Allergy 62, 675-682 (2007).

197. Debinski, W., Miner, R., Leland, P., Obiri, N. I., Puri, R. K.: Receptor for interleukin (IL) 13 does not interact with IL4 but receptor for IL4 interacts with IL13 on human glioma cells. J Biol Chem 271, 22428-22433 (1996).

198. Debinski, W., Dickinson, P., Rossmeisl, J. H., Robertson, J., Gibo, D. M.: New agents for targeting of IL-13RA2 expressed in primary human and canine brain tumors. PLoS ONE 8, e77719 (2013).

199. Debinski, W., Hetal, P., Denise, G.: Multi-level specific targeting of cancer cells with IL-13. US Patent No. 8,362,207 (2013).

200. Grunig, G., Corry, D. B., Reibman, J., Wills-Karp, M.: Interleukin 13 and the evolution of asthma therapy. Am J Clin Exp Immunol 1, 20-27 (2012).

201. Corren, J., Lemanske Jr, R. F., Hanania, N. A., Korenblat, P. E., Parsey, M. V., Arron, J. R., Harris, J. M., Scheerens, H., Wu, L. C., Su, Z.: Lebrikizumab treatment in adults with asthma. N Engl J Med 365, 1088-1098 (2011).

202. Kasaian, M. T., Marquette, K., Fish, S., DeClercq, C., Agostinelli, R., Cook, T. A., Brennan, A., Lee, J., Fitz, L., Brooks, J.: An IL-4/IL-13 dual antagonist reduces lung inflammation, airway hyperresponsiveness, and ige production in mice. Am J Respir Cell Mol Biol 49, 37-46 (2013).

203. Spiess, C., Bevers, J., Jackman, J., Chiang, N., Nakamura, G., Dillon, M., Liu, H., Molina, P., Elliott, J. M., Shatz, W.: Development of a human IgG4 bispecific antibody for dual targeting of interleukin-4 (IL-4) and interleukin-13 (IL-13) cytokines. J Biol Chem 288, 26583-26593 (2013).

204. Sundberg, E. J.: With an antibody whose duty's double, a step towards ending asthma trouble? Biochem J 451, e1-3 (2013).

205. Redpath, N. T., Xu, Y., Wilson, N. J., Fabri, L. J., Baca, M., Andrews, A. E., Braley, H., Lu, P., Ireland, C., Ernst, R. E., Woods, A., Forrest, G., An, Z., Zaller, D. M., Strohl, W. R., Luo, C. S., Czabotar, P. E., Garrett, T. P., Hilton, D. J., Nash, A. D., Zhang, J. G., 
Nicola, N. A.: Production of a human neutralizing monoclonal antibody and its crystal structure in complex with ectodomain 3 of the interleukin-13 receptor alpha1. Biochem J 451, 165-175 (2013).

206. Dunn, R. M., Wechsler, M. E.: Anti-interleukin therapy in asthma. Clin Pharmacol Ther 97, 55-65 (2015).

207. Legrand, F., Klion, A. D.: Biologic therapies targeting eosinophils: Current status and future prospects. J Allergy Clin Immunol Pract 3, 167-174 (2015).

208. Fahy, J. V.: Type 2 inflammation in asthma-present in most, absent in many. Nat Rev Immunol 15, 57-65 (2015). 